\title{
Article \\ Deoxynivalenol and Zearalenone: Different Mycotoxins with Different Toxic Effects in the Sertoli Cells of Equus asinus
}

\author{
Jun-Lin Song ${ }^{1,2}$ and Guo-Liang Zhang ${ }^{1, *}$ \\ 1 College of Animal Science and Technology, Qingdao Agricultural University, Qingdao 266109, China; \\ 201701051@qau.edu.cn \\ 2 Central Laboratory, Qingdao Agricultural University, Qingdao 266109, China \\ * Correspondence: goldenguoliang@163.com
}

Citation: Song, J.-L.; Zhang, G.-L. Deoxynivalenol and Zearalenone: Different Mycotoxins with Different Toxic Effects in the Sertoli Cells of Equus asinus. Cells 2021, 10, 1898. https://doi.org/10.3390/cells10081898

Academic Editor: Artur Mayerhofer

Received: 19 June 2021

Accepted: 22 July 2021

Published: 27 July 2021

Publisher's Note: MDPI stays neutral with regard to jurisdictional claims in published maps and institutional affiliations.

Copyright: (C) 2021 by the authors. Licensee MDPI, Basel, Switzerland. This article is an open access article distributed under the terms and conditions of the Creative Commons Attribution (CC BY) license (https:// creativecommons.org/licenses/by/ $4.0 /)$.

\begin{abstract}
Background: Deoxynivalenol (DON) and zearalenone (ZEA) are type B trichothecene mycotoxins that exert serious toxic effects on the reproduction of domestic animals. However, there is little information about the toxicity of mycotoxins on testis development in Equus asinus. This study investigated the biological effects of DON and ZEA exposure on Sertoli cells (SCs) of Equus asinus; (2) Methods: We administered $10 \mu \mathrm{M}$ and $30 \mu \mathrm{M}$ DON and ZEA to cells cultured in vitro; (3) Results: The results showed that $10 \mu \mathrm{M}$ DON exposure remarkably changed pyroptosis-associated genes and that $30 \mu \mathrm{M}$ ZEA exposure changed inflammation-associated genes in SCs. The mRNA expression of cancer-promoting genes was remarkably upregulated in the cells exposed to DON or $30 \mu \mathrm{M}$ ZEA; in particular, DON and ZEA remarkably disturbed the expression of androgen and oestrogen secretion-related genes. Furthermore, quantitative RT-PCR, Western blot, and immunofluorescence analyses verified the different expression patterns of related genes in DON- and ZEA-exposed SCs; (4) Conclusions: Collectively, these results illustrated the impact of exposure to different toxins and concrete toxicity on the mRNA expression of SCs from Equus asinus in vitro.
\end{abstract}

Keywords: DON; ZEA; Equus asinus; Sertoli cells; pyroptosis; RNA-seq

\section{Introduction}

Deoxynivalenol (DON) and zearalenone (ZEA) are Fusarium mycotoxins produced by Fusarium fungi [1]. DON frequently occurs in the feed of livestock in combination with ZEA [2]. It is inevitable that grains will be contaminated by mycotoxins such as DON or ZEA during growth, storage, and processing [3,4]. Previous in vitro studies demonstrated that DON or ZEA exposure is linked to reproductive disorders in farm animals [5-8], and the toxins cause major economic loss in domestic animal industries [5,9]. In addition, ZEA causes reproductive disorders and demonstrates species-specific, organ-targeted oestrogenic activity in farm animals [10]. The effects include ovarian atrophy in pigs [11], follicular haematomas in horses [5], and reproductive failure in domestic animals [12-15]. However, the specific toxicity of DON and ZEA on reproduction in male Equus asinus is still unclear.

Equus asinus is a domestic animal that serves as a pet and draft animal and is important in mule and milk production worldwide [16,17]. According to the statistics of the Food and Agriculture Organization of the United Nations (FAO), in 2019, there were 50,583,572 Equus asinus in the world, of which 2,600,700 were in China (http: / /www.fao.org/faostat/ $\mathrm{zh} / \#$ data/QA; accessed on 7 June 2021). China has a long history of raising Equus asinus for agriculture and transportation [8,18,19]. Moreover, Equus asinus is the major source of the Chinese traditional tonic E Jiao, the production of which was worth 17.8 billion dollars in 2020. Previous in vitro investigations indicated that DON or ZEA exposure may influence the genomic stability of Equus asinus and porcine granulosa cells (GCs) $[7,20]$. In addition, horses fed oats contaminated with ZEA have a high incidence of follicular haematomas $[5,21]$. The aberrant development of Sertoli cells is also related to some 
primary testicular carcinomas in animals and humans [22,23]. Abnormal expression of functional genes in Sertoli cells such as androgen-regulated homeobox gene (NKX3.1) was seen in testicular Sertoli cell tumors [24].

According to daily testing of mycotoxins in feed from the National Black Equus asinus Breeding Center in China, the annual average levels of DON and ZEA were $646.90 \mu \mathrm{g} / \mathrm{kg}$ and $545.52 \mu \mathrm{g} / \mathrm{kg}$, respectively, in 2020. However, the annual average levels of DON and ZEA were also extremely high compared to US Food and Drug Administration (FDA) mycotoxin regulatory guidance $(<500 \mu \mathrm{g} / \mathrm{kg})$ [25] and European Commission Guidance (EU) standards $(<250 \mu \mathrm{g} / \mathrm{kg})$ [26] for animal feed. In August, the contents of DON and ZEA in forage had reached their annual peak, with monthly averages of $1386.24 \mu \mathrm{g} / \mathrm{kg}$ and $1170.47 \mu \mathrm{g} / \mathrm{kg}$, respectively, which was more than twice as high as the national standard for porcine feed $(<500 \mu \mathrm{g} / \mathrm{kg})$. To date, the national or local standards of mycotoxin content in the forage of Equus asinus have not been publicised in China. But high levels of mycotoxins in feed, especially DON and ZEA, have severely impacted the breeding of Equus asinus.

SCs perform numerous functions in vivo, including secretion of factors and nutrition of germ cells [27], coordinating spermatogenesis and formation of the blood-testis barrier, and phagocytosis of degenerating germ cells [28,29]. There are foetal and adult SC populations that differ in function and age in the testis [30,31]. Only immature SCs can proliferate [29,32]. Therefore, adult SCs have a finite number of germ cells that they can support [32]. Accordingly, the efficiency of spermatogenesis is influenced by SCs, and factors affecting SCs influence testis size and daily sperm production [30]. In addition, SCs are the most widely used testicular cells for in vitro toxicology $[29,33,34]$. The testis is highly vulnerable to xenobiotics and toxins, yet the number of studies undertaken in Equus asinus is insufficient and should be drastically increased.

\section{Materials and Methods}

2.1. Reagents

DON and ZEA were procured from Sigma-Aldrich ${ }^{\circledR}$ (D0156 and Z2125 St. Louis, MO, USA). Stock solutions of DON and ZEA at a concentration of 20,000 $\mu \mathrm{M}$ were prepared by dissolving the toxins in dimethyl sulfoxide (DMSO) and stored at $-80{ }^{\circ} \mathrm{C}$. DMSO (D12345), M-199 medium (11150067), foetal bovine serum (FBS, 10091148), penicillin, and streptomycin were provided by Thermo Fisher Scientific (Waltham, MA, USA). Collagenase IV (C8160), hyaluronidase (H8030), and DNase I (D8071) were provided by Solarbio (Beijing, China). Trypsin-EDTA solution (0.25\%, SH30042.01) was provided by HyClone (Beijing, China).

\subsection{Animals}

Prepubertal Equus asinus testes were collected from the slaughterhouse of Dong E Equus asinus Production Company (Qingdao, China) and maintained at $32^{\circ} \mathrm{C}-35^{\circ} \mathrm{C}$ Hank's balanced salt solution (Sigma-Aldrich, St. Louis, MO, USA) for the isolation of SCs. All Equus asinus used in the experiment were fed and treated humanely during slaughter (no. 11002009000012, production license number: SCXK: 2020-7077, Qingdao, China).

All animal experiments were performed in accordance with Chinese welfare guidelines and approved by the Institutional Animal Ethical Committee of Qingdao Agricultural University (DEC 2020-019). All experiments were performed in accordance with relevant guidelines and regulations.

\subsection{Dose Selection}

The annual average dose of DON and ZEA from the "National Black Equus asinus Breeding Center" in 2020 was selected and translated to SCs in vitro. The doses of toxins were standardised according to the results of previous studies on ZEA-induced impairments in the fertility of Equus asinus, pigs, and mice [8,35]. DMSO was used as the vehicle for DON and ZEA. For accuracy, the same dose of DMSO added to the $10 \mu \mathrm{M}$ and $30 \mu \mathrm{M}$ 
DON or ZEA groups was added to the control group. Culture media were supplemented with DMSO at a final concentration of $0.1 \%$.

\subsection{Isolation and Culture of Equus asinus SCS}

Equus asinus testes were collected and transported to the laboratory at $37{ }^{\circ} \mathrm{C}$ with $10 \%$ $(v / v)$ antibiotic-antimycotic solution (Sangon Biotech, Shanghai, China) for $30 \mathrm{~min}$. The testes were longitudinally split, and the tissue was fragmented into fine pieces by surgical scissors and digested using $1.5 \mathrm{mg} / \mathrm{mL}$ collagenase IV and $0.2 \%$ hyaluronidase mixed solution (Sigma-Aldrich, St. Louis, MO, USA) in HBSS at $37^{\circ} \mathrm{C}$ for $30 \mathrm{~min}$. Then, $10 \mu \mathrm{g} / \mathrm{mL}$ DNase I and $0.25 \%$ trypsin were used to digest the mixed solution at $37^{\circ} \mathrm{C}$ for $15 \mathrm{~min}$. The digested cells were filtered through $74 \mu \mathrm{m}$ nylon mesh (Sangon Biotech, Shanghai, China). A sedimentation step collected cell clumps at the bottom of a tube after separating the filtered cells under unit gravity by incubating in a $15 \mathrm{~mL}$ tube (Corning, NY, USA) at room temperature for $10 \mathrm{~min}$. This procedure was repeated twice to remove debris included in the cell clump. Subsequently, an adherent step separated the attached SCs and suspended cells by incubating the clumped cells on a $10 \mathrm{~cm}$ culture plate (Corning, NY, USA) at $37^{\circ} \mathrm{C}$ for $20 \mathrm{~min}$, which was repeated three times. Finally, isolated SCs were identified using immunohistochemistry methods. The fibroblast used for the contrast group being cultured from the cell clump of Equus asinus testes.

\subsection{Flow Cytometry Analysis of Apoptosis}

SCs were treated with DON and ZEA at $10 \mu \mathrm{M}$ and $30 \mu \mathrm{M}$ for $72 \mathrm{~h}$. Then, they were collected and washed three times using PBS. An Annexin V-FITC/7-AAD kit (Sino Biological, APK10448-F, Beijing, China) was used to detect apoptosis or necrosis of Equus asinus SCs by flow cytometry according to the manufacturer's instructions.

\subsection{Immunofluorescence and Cell Counting}

Cultured SCs were fixed in $4 \%$ paraformaldehyde for $2 \mathrm{~h}$, heated at $42{ }^{\circ} \mathrm{C}$ for another $2 \mathrm{~h}$, and fixed on polysine-coated slides. SC sections were blocked with $10 \%$ goat serum for 40 min and incubated with primary antibodies overnight at $4{ }^{\circ} \mathrm{C}$ (Table 1). Subsequently, the sections were incubated for $1.5 \mathrm{~h}$ at $37^{\circ} \mathrm{C}$ with Alexa Fluor 488/Alexa Fluor 594-goat anti-rabbit secondary antibody at a dilution of 1:100 (ABclonal, AS053/AS039, Wuhan, China). The sections were incubated for 5 min with Hoechst 33,342 (Solarbio, C0031) to visualise the nuclei of SCs. Immune signals were detected using a fluorescence microscope (Olympus, XB51, Japan), and captured images were analysed in accordance with the ImageJ standard.

Table 1. Primary antibodies.

\begin{tabular}{cccc}
\hline Proteins & Article Number & Producer & Origin \\
\hline GAPDH & AC001 & ABclone & Wuhan, China \\
GSDMD-N & A20197 & ABclone & Wuhan, China \\
Caspase-1 & A0964 & ABclone & Wuhan, China \\
CCL 17 & A2854 & ABclone & Wuhan, China \\
IL 10 RA & A1830 & ABclone & Wuhan, China \\
ESR 1 & A1668 & ABclone & Wuhan, China \\
PRDX 4 & A1486 & ABclone & Wuhan, China \\
SOX 9 & A2479 & ABclone & Wuhan, China \\
MSH 6 & A0983 & ABclone & Wuhan, China \\
CDK 1 & A0220 & ABclone & Wuhan, China \\
CCNB 2 & A3351 & ABclone & Wuhan, China \\
AR & A2053 & ABclone & Wuhan, China \\
NOX 1 & A12309 & ABclone & Wuhan, China \\
\hline
\end{tabular}




\subsection{Western Blot Analysis}

Proteins isolated from SCs were used for Western blot analysis in accordance with previous standard methods $[36,37]$. Proteins from SCs in each treatment group were separated through 10\% SDS-PAGE and transferred to PVDF membranes. The membranes were incubated overnight at $4{ }^{\circ} \mathrm{C}$ with primary antibodies (Table 1), rinsed three times with TBST, and incubated for $2 \mathrm{~h}$ at $37^{\circ} \mathrm{C}$ with secondary antibodies (Sangon Biotech, D110058) in TBST. Related proteins were detected using AlphaImager ${ }^{\circledR}$ (ProteinSimple, 92-13824-00, San Jose, CA, USA) HP. The intensity of all bands was quantified with GAPDH as the internal control using Image software.

\subsection{TUNEL Staining}

The apoptosis rates of SCs were evaluated using a TUNEL BrightRed Apoptosis Detection Kit (Vazyme, A11302, Nanjing, China). Briefly, SCs were fixed for $2 \mathrm{~h}$ with $4 \%$ paraformaldehyde after $72 \mathrm{~h}$ of exposure to 0,10 , or $30 \mu \mathrm{M}$ DON and ZEA. After the TUNEL reaction, the cells were observed under fluorescence microscopy in accordance with the manufacturer's instructions. TUNEL-positive cells were detected and counted under fluorescence microscopy (Olympus, XB51, Tokyo, Japan). More than 2000 SCs were obtained from each group and counted. Three biological replicates were used for analysis of the TUNEL-positive cell ratio.

\subsection{RNA Extraction, Reverse Transcription, and RNA-Seq}

RNAex pro reagent (AG, AG21101, Beijing, China) was used to extract total RNA from cultured DON- and ZEA-exposed SCs in accordance with the manufacturer's instructions. Then, mRNA was reverse transcribed into first-strand cDNA with a cDNA synthesis kit (TransGen, AT311-03, Beijing, China), referring to a previous study [35,38]. The Novogene Company performed RNA sequencing with the 4000 platform (Beijing, China).

\subsection{Identification of Differentially Expressed Genes}

The NovoMagic and R Bioconductor/DESeq2 packages were used to identify differentially expressed genes (DEGs) between different groups of SCs $(0,10$, and $30 \mu \mathrm{M}$ DON and ZEA treatment groups). Raw counts for differential expression analysis were obtained by using NovoMagic online and checked by using our own normalisation approach [35,39]. Data for differential expression analysis were previously normalised through other methods to prevent possible biases $[40,41]$. The $\log 2$ I fold change I was disallowed as the filter condition because the sequencing design contained biological replicates for each group. Adjusted $p<0.01$ was considered statistically significant.

\subsection{GO and KEGG Enrichment Analysis}

The functional profiles of DEGs were analysed through GO functional enrichment and KEGG pathway analysis by using NovoMagic. NovoMagic is the analysis platform developed by Novogene Company that can visualise GO and KEGG analysis results for DEGs online. In GO analysis, genes can be categorised as molecular function, biological process, and cellular component. NovoMagic was applied to visualise the KEGG analysis results. The $\log 2$ I fold change I value of DEGs reflects the active status of enriched signalling pathways. Adjusted $p<0.05$ was considered statistically significant.

\subsection{Quantitative Real-Time PCR}

Total RNA extraction and cDNA reverse transcription were performed as previously described. A SYBR ${ }^{\circledR}$ Green Premix Pro Taq HS qPCR Kit was used to perform quantitative real-time PCR (RT-qPCR) on a LightCycler ${ }^{\circledR} 96$ RT-PCR instrument (Roche, Germany). RT-qPCR was performed under the following cycling conditions: $30 \mathrm{~s}$ at $95^{\circ} \mathrm{C} ; 40$ cycles at $95^{\circ} \mathrm{C}(5 \mathrm{~s}), 60{ }^{\circ} \mathrm{C}(30 \mathrm{~s})$, and $72{ }^{\circ} \mathrm{C}(30 \mathrm{~s})$; melting at $95^{\circ} \mathrm{C}(1 \mathrm{~s}), 65^{\circ} \mathrm{C}(15 \mathrm{~s})$, and $95^{\circ} \mathrm{C}$ $(1 \mathrm{~s})$; and a final cooling step at $4^{\circ} \mathrm{C}$. The RT-qPCR primers used in this study are listed in Table 2. GAPDH was used as the reference gene for the normalisation of mRNA expression 
in SCs. Gene expression was quantified through the $2-\Delta \Delta \mathrm{CT}$ method. The expression level of each gene is expressed as the mean \pm standard deviation (SD), which was calculated from the data of at least three independent biological replicates.

Table 2. Primers used for quantitative-PCR.

\begin{tabular}{|c|c|c|c|}
\hline Genes & Sequences of Primers $\left(5^{\prime}\right.$ to $\left.3^{\prime}\right)$ & Products & Genbank \\
\hline$G A P D H$ & $\begin{array}{l}\text { F: GAAAGCTGCCAAATACGATGAG } \\
\text { R: GAAGGTGGAAGAGTGGATGTC }\end{array}$ & 136 & XM_014866500.1 \\
\hline Caspase-1 & $\begin{array}{l}\text { F: GGGCACGGGTACAGTAAATAG } \\
\text { R: CGGGCCTTATCCATAACTGTAG }\end{array}$ & 114 & XM_014851328.1 \\
\hline GSDMD & $\begin{array}{l}\text { F: GTTATTGGCTCTGACTGGGAC } \\
\text { R: TGAATCCTGACACGCTCTTG }\end{array}$ & 148 & XM_014858171.1 \\
\hline CCL 17 & $\begin{array}{l}\text { F: ACTGAAGATGCTGTTCCTGG } \\
\text { R: GAAGTACTCCAGACAGCACTC }\end{array}$ & 106 & XM_014827258.1 \\
\hline IL $10 R A$ & $\begin{array}{l}\text { F: GTGGATGAAGTGACTCTGACAG } \\
\text { R: CTCGGAAGTTAGGGAAGATGC }\end{array}$ & 139 & XM_014855577.1 \\
\hline IL 32 & $\begin{array}{l}\text { F: CAACTCAAGACACCCTCCC } \\
\text { R: AAGTAGCTCGAAACAGGCG }\end{array}$ & 136 & XM_014833201.1 \\
\hline IL $23 A$ & $\begin{array}{l}\text { F: GATGGCTGTGATCCTGAAGG } \\
\text { R: TCCCCTGTGAAAATGTCTGAG }\end{array}$ & 113 & XM_014843912.1 \\
\hline$A R$ & $\begin{array}{l}\text { F: AGAGTTGTGTAAGGCAGTGTC } \\
\text { R: TACATGCAATCTCCCCGAAG }\end{array}$ & 96 & XM_014832024.1 \\
\hline AIG 1 & $\begin{array}{l}\text { F: AGTGGGAACCAAGAACAAGAG } \\
\text { R: CAGTACGGCTAACATCCAGTC }\end{array}$ & 72 & XM_014850699.1 \\
\hline ESR 1 & $\begin{array}{l}\text { F: GAAGAGACAAACCAAAGCCAG } \\
\text { R: GCCTCCCCAGTGATGTAATATG }\end{array}$ & 83 & XM_014827966.1 \\
\hline ESR 2 & $\begin{array}{l}\text { F: AGAGGGAAAATGCGTAGAAGG } \\
\text { R: CAGGGTACATACTGGAGTTGAG }\end{array}$ & 143 & XM_014853708.1 \\
\hline MSH 6 & $\begin{array}{l}\text { F: TTCTCTGGTGCTTGTGGATG } \\
\text { R:ATGGTAGTGGTAGAAAACAGTG }\end{array}$ & 130 & XM_014833021.1 \\
\hline MCM 6 & $\begin{array}{l}\text { F: GTGAAGGAGTGGGAGAAAGTG } \\
\text { R: AAAGAGCATCAGAAGGACACC }\end{array}$ & 129 & XM_014849526.1 \\
\hline POLD 1 & $\begin{array}{l}\text { F: TCCGTCATGTGCCGATTC } \\
\text { R: GTAGACCTTCTCAAACTCCAGC }\end{array}$ & 123 & XM_014830334.1 \\
\hline$C D K 1$ & $\begin{array}{l}\text { F: CTTGCCAGAGCTTTTGGAATAC } \\
\text { R: ACCTATACTCCAAATGTCAACCG }\end{array}$ & 129 & XM_014833411.1 \\
\hline CCNB 2 & $\begin{array}{l}\text { F: AACAGAGTTACAACCAGAGCC } \\
\text { R: GCCAATATTTCCATCTGCACTG }\end{array}$ & 143 & XM_014835324.1 \\
\hline PFKM & $\begin{array}{l}\text { F: TCCAACTACCTGAACATCGTG } \\
\text { R: GCGTCTACAATCTCTATGATCCG }\end{array}$ & 116 & XM_014850046.1 \\
\hline PRDX 4 & $\begin{array}{l}\text { F: CTCTGAATGACCTTCCTGTGG } \\
\text { R: TCGGTGTACTGGAATGCTTG }\end{array}$ & 73 & XM_014867883.1 \\
\hline NOX 1 & $\begin{array}{l}\text { F: ACTACCGTCTCTTCCTTACCG } \\
\text { R: GCAGAAAACTCATTGTCCCAC }\end{array}$ & 142 & XM_014859678.1 \\
\hline
\end{tabular}

\subsection{Scanning Electron Microscopy (SEM)}

The treated SCs were washed with PBS 3 times, centrifuged for $10 \mathrm{~min}$ at $3000 \mathrm{rpm}$ at $4{ }^{\circ} \mathrm{C}$ and fixed with $2.5 \%$ glutaraldehyde overnight. Next, tert-butanol was used to separate the glutaraldehyde. After being air-dried, the slides were critical-point dried, mounted on stubs, sputter-coated with a thin layer of conductive metal, gold, and palladium, and viewed by SEM (Hitachi HT7700, Hitachi, Ltd., Tokyo, Japan).

\subsection{Statistical Methods}

Data are presented as the mean \pm SD. The statistical significance of different effects among the control, DON and ZEA exposure groups of SCs was determined through oneway ANOVA for multiple comparisons. All analyses were conducted using GraphPad Prism analysis software (San Diego, CA, USA). All experiments were repeated at least three times, and the results were considered significant at $p<0.05$. 


\section{Results}

\subsection{Apoptosis Rates and DEGs of Equus asinus SCs Exposed to DON and ZEA}

First, we examined the purity of isolated SCs. The isolated cells were identified as SOX9 (a specific Sertoli cell marker)-positive [42] using immunohistochemistry methods (purity of isolated SCs > 97\%) (Figure 1A,B). Then, we exposed the SCs to 10 or $30 \mu \mathrm{M} \mathrm{DON}$ and ZEA for $72 \mathrm{~h}$ of in vitro culture (Figure 1C). As shown in Figure 2, flow cytometry analysis was used to investigate the effects of DON and ZEA on cell apoptosis (Figure 2A). The results showed that the apoptosis rate was significantly increased under DON and ZEA treatment $(10 \mu \mathrm{M}$ DON: $16.60 \% \pm 1.39 \% ; 30 \mu \mathrm{M}$ DON: $22.05 \% \pm 1.11 \% ; 10 \mu \mathrm{M}$ ZEA: $8.06 \% \pm 0.49 \% ; 30 \mu \mathrm{M}$ ZEA: $14.58 \% \pm 1.42 \%)$ relative to that under the control treatment $(0 \mu \mathrm{M}$ DON: $4.47 \% \pm 0.24 \%$; $0 \mu \mathrm{M}$ ZEA: $4.72 \% \pm 0.31 \% ; p<0.05$ or $p<0.01$; Figure 2B,C). Interestingly, $10 \mu \mathrm{M}$ DON exposure remarkably increased the apoptosis rate of SCs compared with $30 \mu \mathrm{M}$ ZEA treatment. From Figure S1, the percentages of TUNEL-positive SCs also remarkably increased under DON and ZEA treatment $(10 \mu \mathrm{M}$ DON: $22.72 \% \pm 1.79 \%$; $30 \mu \mathrm{M}$ DON: $64.15 \% \pm 3.15 \% ; 10 \mu \mathrm{M}$ ZEA: $15.36 \% \pm 2.79 \% ; 30 \mu \mathrm{M}$ $\mathrm{ZEA}: 24.17 \% \pm 2.22 \%$ ) relative to those under the control treatment ( $0 \mu \mathrm{M}$ DON: $3.07 \% \pm$ $0.14 \%$; $0 \mu \mathrm{M}$ ZEA: 3.32\% $\pm 0.61 \% ; p<0.01$; Figure S1).

A
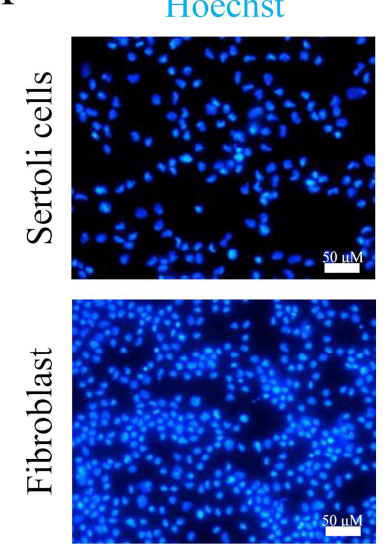

C

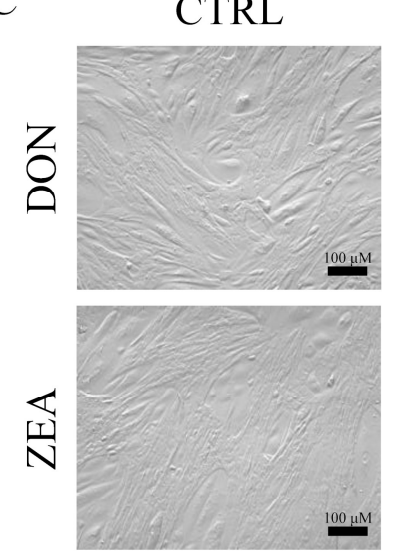

SOX 9
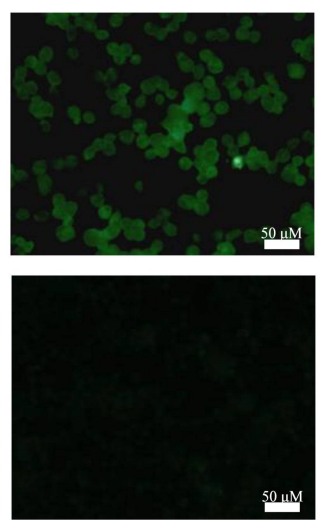

$10 \mu \mathrm{M}$

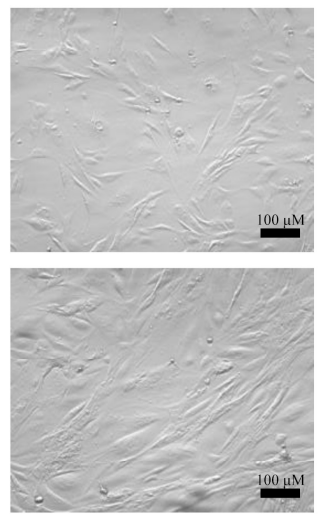

Merge
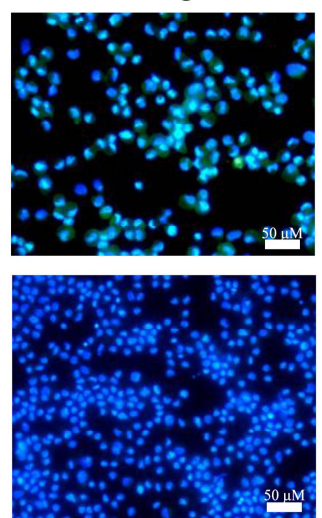

$30 \mu \mathrm{M}$

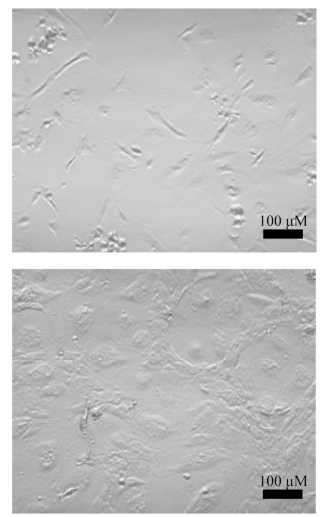

B

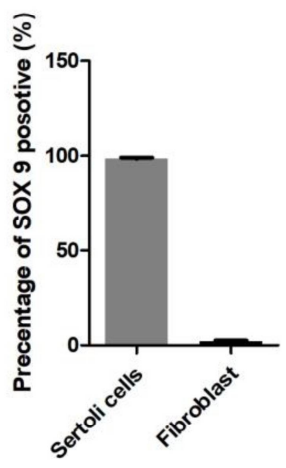

Figure 1. The purity of isolated SCs, as well as DON and ZEA exposure, affect the morphology of Equus asinus SCs. (A) The isolated cells were identified by SOX9 positivity using immunohistochemistry methods, and fibroblasts were used for contrast. Bar indicates $50 \mu \mathrm{m}$. (B) The percentages of SOX9-positive SCs. (C) The morphology of SCs following administration of $0 \mu \mathrm{M}, 10 \mu \mathrm{M}$, and $30 \mu \mathrm{M}$ DON and ZEA after $72 \mathrm{~h}$ of culture in vitro. Bar indicates $100 \mu \mathrm{m}$. 
A
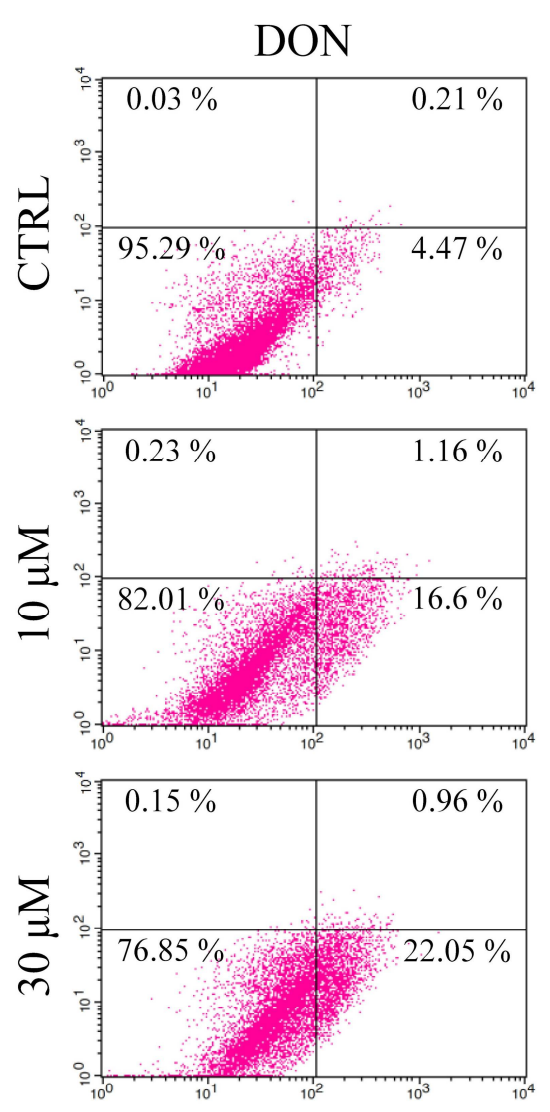
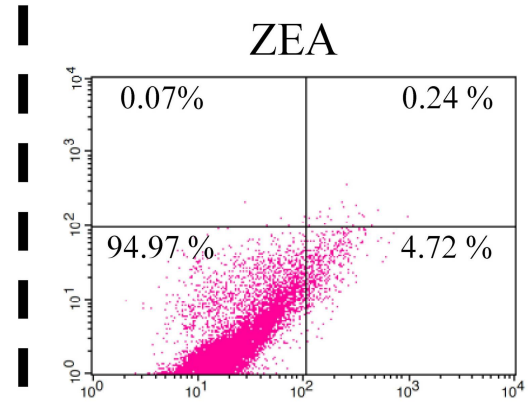

I
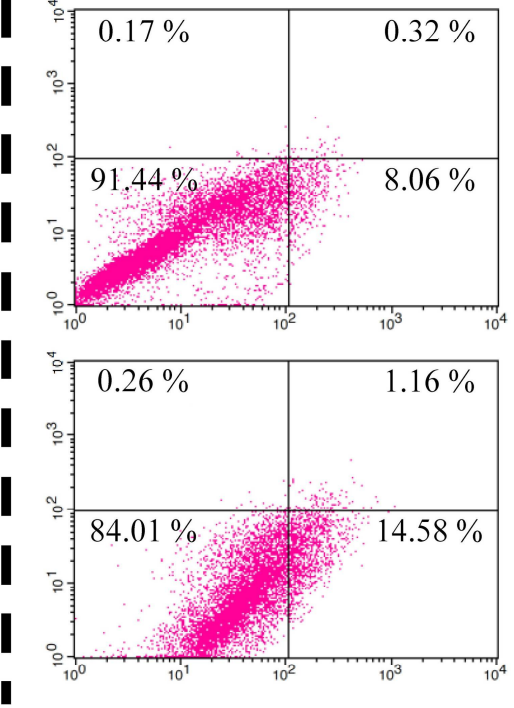

B

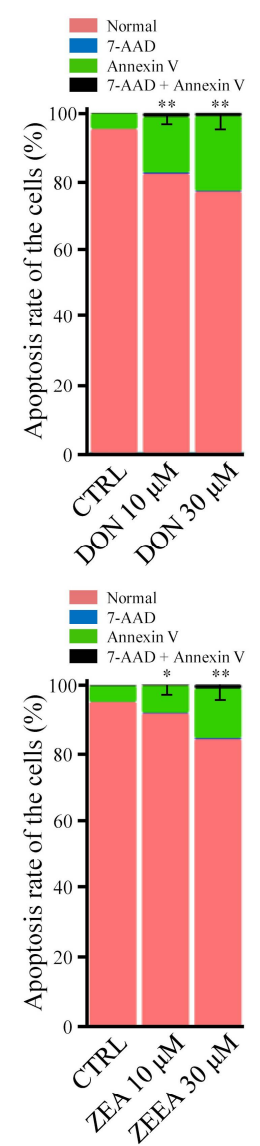

Figure 2. The effect of DON and ZEA on SCs apoptosis, analysed by flow cytometry. (A) The apoptosis results of SCs following administration of $0 \mu \mathrm{M}, 10 \mu \mathrm{M}$, and $30 \mu \mathrm{M}$ DON and ZEA after $72 \mathrm{~h}$ of culture in vitro. (B) The apoptosis rate of SCs after $0 \mu \mathrm{M}, 10 \mu \mathrm{M}$, and $30 \mu \mathrm{M}$ DON treatment. ${ }^{* *} p<0.01$. (C) The apoptosis rates of SCs after exposure to $0 \mu \mathrm{M}, 10 \mu \mathrm{M}$, and $30 \mu \mathrm{M}$ ZEA treatment. ${ }^{*} p<0.05 ;{ }^{* *} p<0.01$.

Nine libraries from the three groups were sequenced, and 715,715,682 raw reads (GEO accession number: GSE172037), with 703,892,136 clean reads, were obtained. Then, we performed RNA-seq analysis to confirm the effects of DON and ZEA exposure on SCs (Figure 3). We screened a total of 9393 and 6065 DEGs in the DON and ZEA treatment groups, respectively, based on the research criterion FDR $<0.05$ (Figure 3F). We found that 3300 and 3251 genes were up- and downregulated under $10 \mu \mathrm{M}$ DON treatment, while 4841 and 3764 genes were up- and downregulated under $30 \mu \mathrm{M}$ DON treatment, respectively (Figure 3A,B). Furthermore, we identified 2816 and 3131 DEGs that were upand downregulated under $30 \mu \mathrm{M}$ ZEA treatment, while only 391 and 412 DEGs were upand downregulated under $10 \mu \mathrm{M}$ ZEA treatment, respectively (Figure 3C,D). Meanwhile, we selected some DEGs between the mycotoxin and control groups with degrees greater than 20 to form a heat map (Figure 3E). 
A

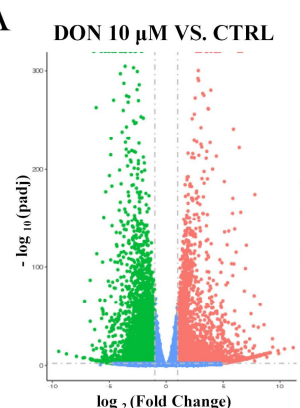

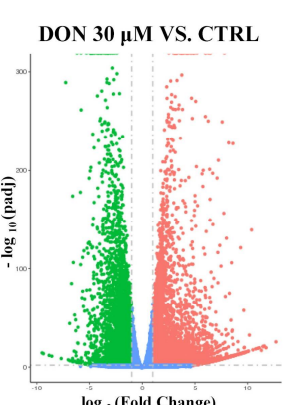

$\log _{2}$ (Fold Change)

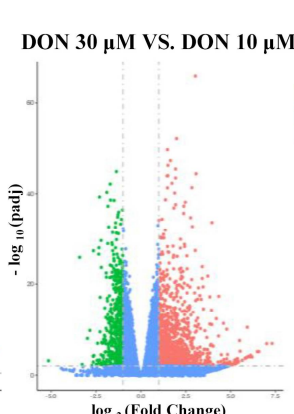

$\log _{2}$ (Fold Change)

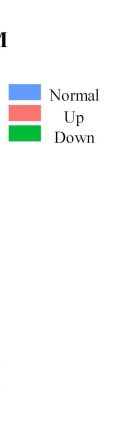

B

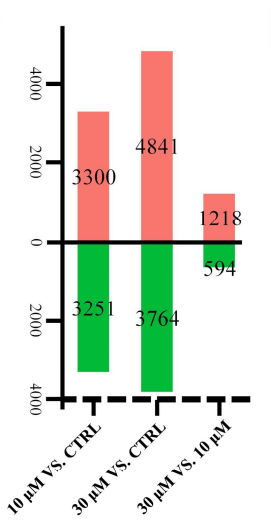

D
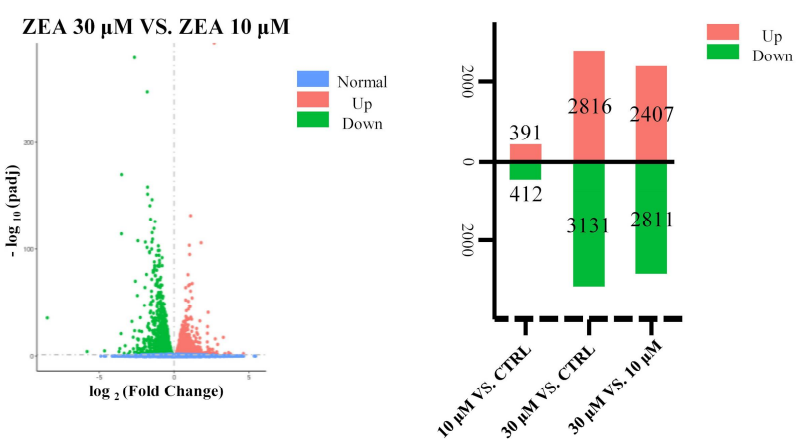

F

E
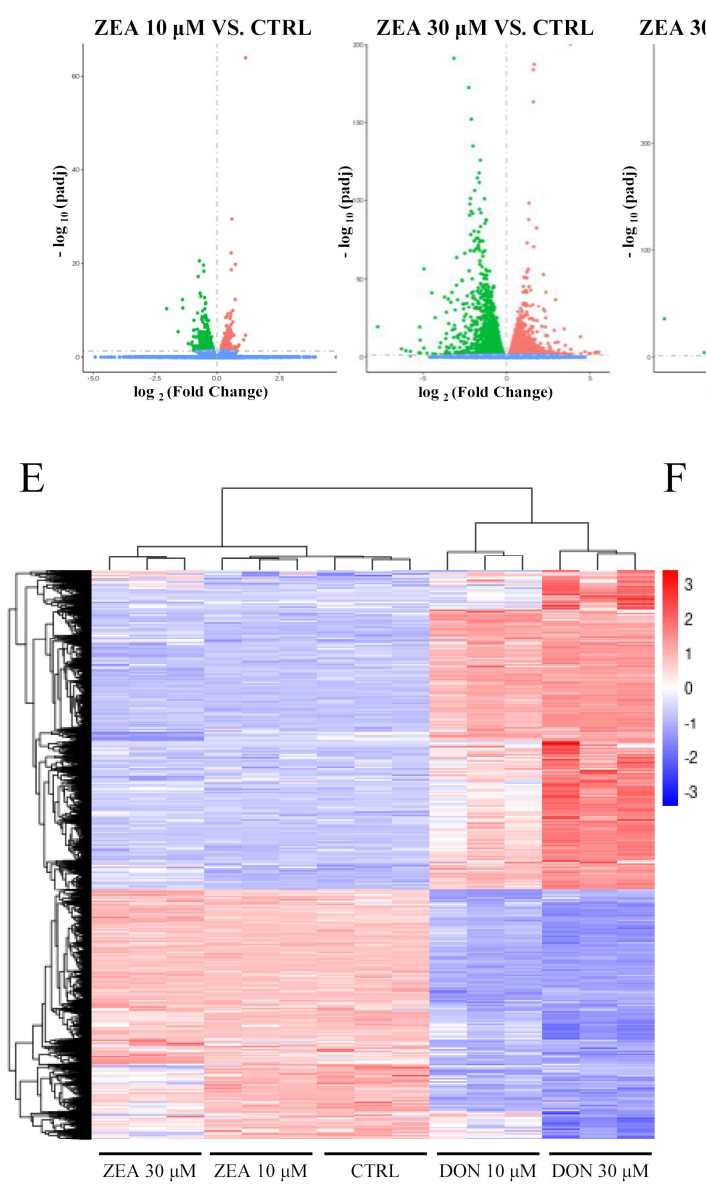

DON $10 \mu \mathrm{M}$ VS. CTRL DON $30 \mu \mathrm{M}$ VS. CTRL
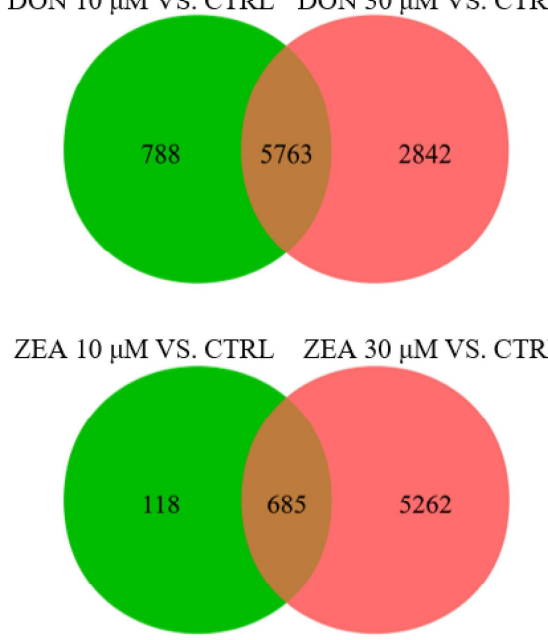

Figure 3. Gene expression profiles of SCs after DON and ZEA treatment. (A) Scatterplot of gene expression after DON treatment; $10 \mu \mathrm{M}$ DON treatment group vs. Control group, $30 \mu \mathrm{M}$ DON treatment group vs. Control group, $30 \mu \mathrm{M}$ DON treatment group vs. $10 \mu \mathrm{M}$ DON treatment group. Green and red plots represent differentially expressed genes. (B) Comparison of DEGs among the control, $10 \mu \mathrm{M}$ and $30 \mu \mathrm{M}$ DON-treated groups. (C) Scatterplot of gene expression after ZEA treatment; $10 \mu \mathrm{M}$ ZEA treatment group vs. control group, $30 \mu \mathrm{M}$ ZEA treatment group vs. control group, 30 $\mu \mathrm{M}$ ZEA treatment group vs. $10 \mu \mathrm{M}$ ZEA treatment group. Green and red plots represent differentially expressed genes. (D) Comparison of DEGs among the control, $10 \mu \mathrm{M}$ and $30 \mu \mathrm{M}$ ZEA treated groups. (E) Heatmap indicating the group difference of DEGs in the $10 \mu \mathrm{M}$ and $30 \mu \mathrm{M}$ DON and ZEA treated groups compared with the control group, and the repeatability within each group. The results are presented as the means \pm SD. All experiments were repeated at least three times. (F) Venn diagram showing the differential expression of 9393 and 6065 genes in the DON and ZEA treated groups compared to the control groups. 
We annotated the functional interactions of genes that were differentially expressed between the control and DON or ZEA treatment groups by using the STRING database to investigate the potential effects of mycotoxin exposure on SCs. Search Tool for the Retrieval of Interacting Genes/Proteins (STRING, https: / /string-db.org/; accessed on 7 June 2021) is a database of protein-protein interaction. This database contains the direct and physically related interactions between known and predicted protein and genes. The $\mathrm{R}$ Bioconductor/STRINGdb was applied for PPI of interested DEGs [43].

\subsection{DEGs Involved in GO Classification and KEGG Pathways}

We applied the NovoMagic and R packages to annotate the GO enrichment functions of DEGs in each group (Figure $4 \mathrm{~A}-\mathrm{C}$ ). We found that DEGs in DNA metabolic process, immune system process, DNA repair, and apoptotic process (Figure 4A) were remarkably enriched in SCs exposed to $10 \mu \mathrm{M}$ and $30 \mu \mathrm{M}$ DON. Meanwhile, DEGs involved in the small molecular metabolic process, immune system process, DNA metabolic process, and cell cycle were remarkably enriched in SCs exposed to $10 \mu \mathrm{M}$ and $30 \mu \mathrm{M}$ ZEA (Figure 4B). Moreover, DEGs were significantly enriched in the regulation of apoptotic processes in SCs exposed to $30 \mu \mathrm{M}$ ZEA (Figure 4C). In addition, upregulated DEGs in SCs under $10 \mu \mathrm{M}$ DON treatment were significantly enriched in the immune system and apoptotic processes $(p<0.001)$. Downregulated DEGs in SCs exposed to $10 \mu \mathrm{M}$ ZEA were significantly enriched in the steroid biosynthesis process [8].

A

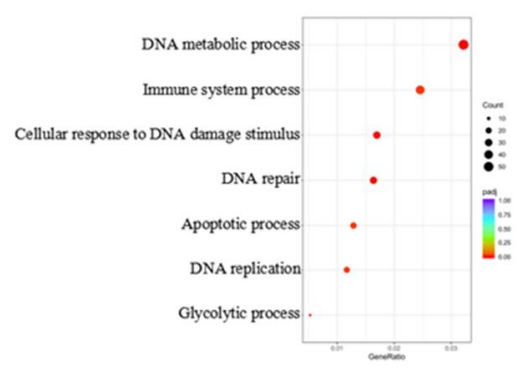

$\mathrm{D}$

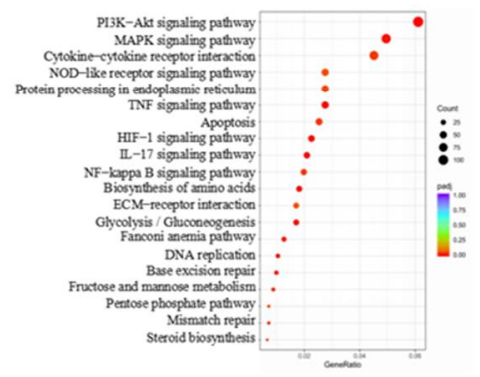

$\mathrm{B}$

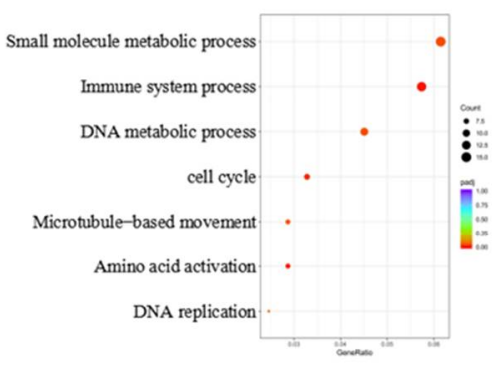

E

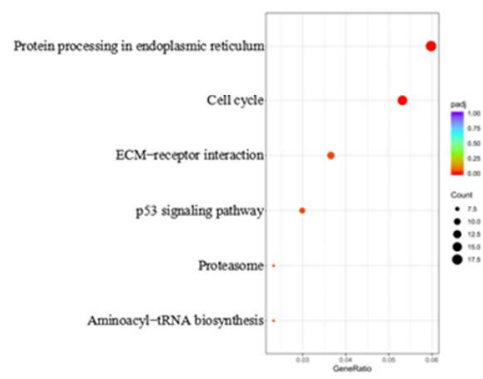

$\mathrm{C}$

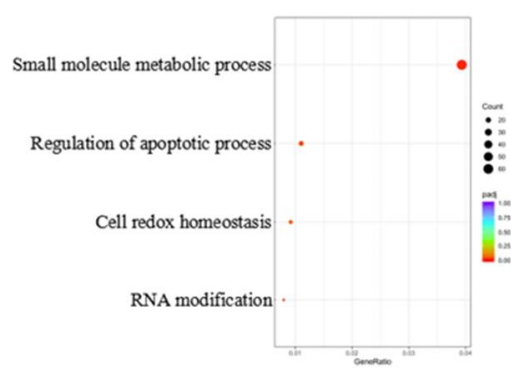

F

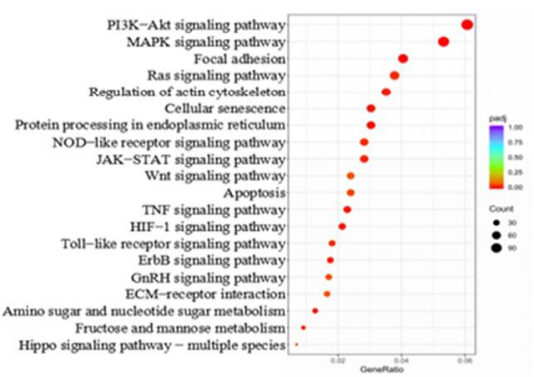

Figure 4. GO and KEGG biological processes involving DEGs in Equus asinus SCs exposed to DON and ZEA. (A) GO enrichment of 5763 DEGs in the $10 \mu \mathrm{M}$ and $30 \mu \mathrm{M}$ DON-exposed Equus asinus SCs, including biological process, cellular component, and molecular function. (B) GO enrichment of 685 DEGs in the $10 \mu \mathrm{M}$ and $30 \mu \mathrm{M}$ ZEA-treated Equus asinus SCs. (C) GO enrichment of 5262 DEGs in the SCs of $30 \mu \mathrm{M}$ ZEA treatment group. (D) KEGG enrichment of the 5763 DEGs in the $10 \mu \mathrm{M}$ and $30 \mu \mathrm{M}$ DON-exposed Equus asinus SCs. (E) KEGG enrichment of the 685 DEGs in the $10 \mu \mathrm{M}$ and $30 \mu \mathrm{M} Z \mathrm{ZEA}$ treated group. (F) KEGG enrichment of the 5262 DEGs of $30 \mu \mathrm{M}$ ZEA treatment group. The lengths of the bars indicate the number of DEGs that are enriched in each pathway. The blue to red gradient represents the p.adjust trend from high to low.

We used NovoMagic and the clusterProfiler R package to identify extremely affected KEGG pathways to obtain insight into the function of DEGs (Figure 4D-F). DEGs in SCs exposed to $10 \mu \mathrm{M}$ and $30 \mu \mathrm{M}$ DON were significantly enriched in the PI3K/AKT [35], MAPK, and TNF signalling pathways (Figure 4D). Meanwhile, DEGs in SCs treated with 
$10 \mu \mathrm{M}$ and $30 \mu \mathrm{M}$ ZEA were significantly enriched in the regulation of the cell cycle and P53 signalling pathway (Figure 4E). In addition, we identified DEGs that were significantly enriched in the PI3K/AKT [35], MAPK, and Hippo signalling pathways after $30 \mu \mathrm{M}$ ZEA treatment (Figure $4 \mathrm{~F}$ ).

The results of GO and KEGG pathway analyses revealed that POLD1, Caspase1, GS$D M D, C C L 17$, and PRDX4, which are involved in DNA metabolism, pyroptosis, and inflammation processes, were differentially expressed in SCs exposed to $10 \mu \mathrm{M}$ and $30 \mu \mathrm{M}$ DON. The CDK1, CCNB2, ESR1, and NOX1 genes involved in the cell cycle and steroidrelated signalling pathways were changed in SCs exposed to $30 \mu \mathrm{M} Z$ ZEA. WNT2, MSH6, $R A F$, and Cyclin D1 (CCND1), genes involved in cancer processes, were also differentially expressed after exposure to $10 \mu \mathrm{M}$ and $30 \mu \mathrm{M}$ DON.

\subsection{Cellular and Molecular Effects of DON and ZEA Exposure on SCs}

Exposure to 10 and $30 \mu \mathrm{M}$ DON may lead to the pyroptosis of SCs (Figures 5-7), and DON and ZEA might induce inflammation and endocrine effects in SCs through different molecular mechanisms (Figures 8-11).

As shown in Figure 5, the number of immunofluorescence-positive genes, such as Caspase1 (Figure 5A-C) and GSDMD (Figure 5D-F), remarkably increased in the $10 \mu \mathrm{M}$ and $30 \mu \mathrm{M}$ DON groups, whereas the genes showed no significant differences in SCs treated with $10 \mu \mathrm{M}$ and $30 \mu \mathrm{M}$ ZEA relative to those in the control group. Moreover, exposure to $10 \mu \mathrm{M}$ and $30 \mu \mathrm{M}$ DON significantly upregulated the mRNA abundance and protein levels of Caspase1 (Figure 6A-C) in SCs. In addition, the mRNA abundance and protein levels of GSDMD (Figure 6B) and GSDMD-N (Figure 6D) were increased after the treatment of $10 \mu \mathrm{M}$ and $30 \mu \mathrm{M}$ DON. Representative SEM images indicated that SCs treated with $10 \mu \mathrm{M}$ and $30 \mu \mathrm{M}$ DON undergo membrane perforation and produce apoptotic body-like cell protrusions prior to plasma membrane rupture [44] (Figure 7). However, there were no significant differences in SCs treated with $10 \mu \mathrm{M}$ ZEA compared with the control group (Figure 7).

Immunohistochemical results of SCs exposed to the mycotoxin indicated that the number of CCL17-positive cells remarkably increased in the $10 \mu \mathrm{M}$ and $30 \mu \mathrm{M}$ DON exposure groups (Figure $8 \mathrm{~A}-\mathrm{C}$ ), while there was a significantly increased number of IL10RA-positive cells in the $10 \mu \mathrm{M}$ and $30 \mu \mathrm{M}$ ZEA treatment groups (Figure 8D-F). The mRNA abundance and protein levels of CCL17 and IL10RA were significantly upregulated in SCs exposed to $10 \mu \mathrm{M}$ and $30 \mu \mathrm{M}$ DON $(p<0.05$ or $p<0.01$; Figure 9A,C) and ZEA $(p<$ 0.05 or $p<0.01$; Figure $9 \mathrm{~B}, \mathrm{D})$ relative to those in SCs under the control treatment.

As shown in Figure 10, the number of immunofluorescence-positive genes, such as $A R$, remarkably decreased in the $10 \mu \mathrm{M}$ and $30 \mu \mathrm{M}$ DON exposure groups (Figure 10A-C), whereas the expression of ESR1 genes was significantly increased in SCs treated with $10 \mu \mathrm{M}$ and $30 \mu \mathrm{M}$ ZEA (Figure 10D-F) relative to those in the control group. Moreover, exposure to $10 \mu \mathrm{M}$ and $30 \mu \mathrm{M}$ DON significantly downregulated the mRNA abundance and protein levels of the $A R$ gene (Figure 11A,C), while ZEA exposure significantly upregulated the expression of the ESR1 gene (Figure 11B-D) in SCs. 
A
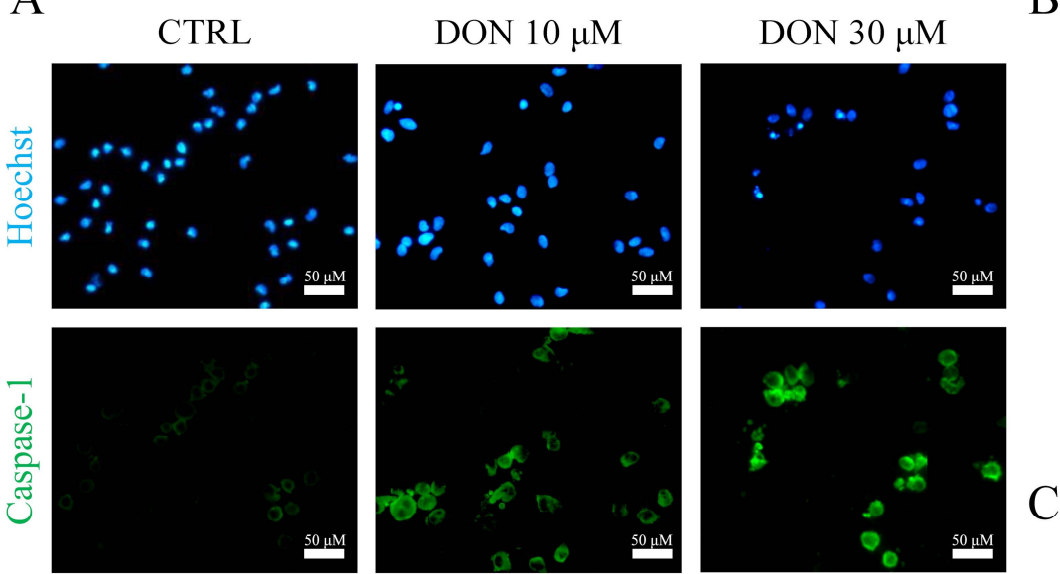

B
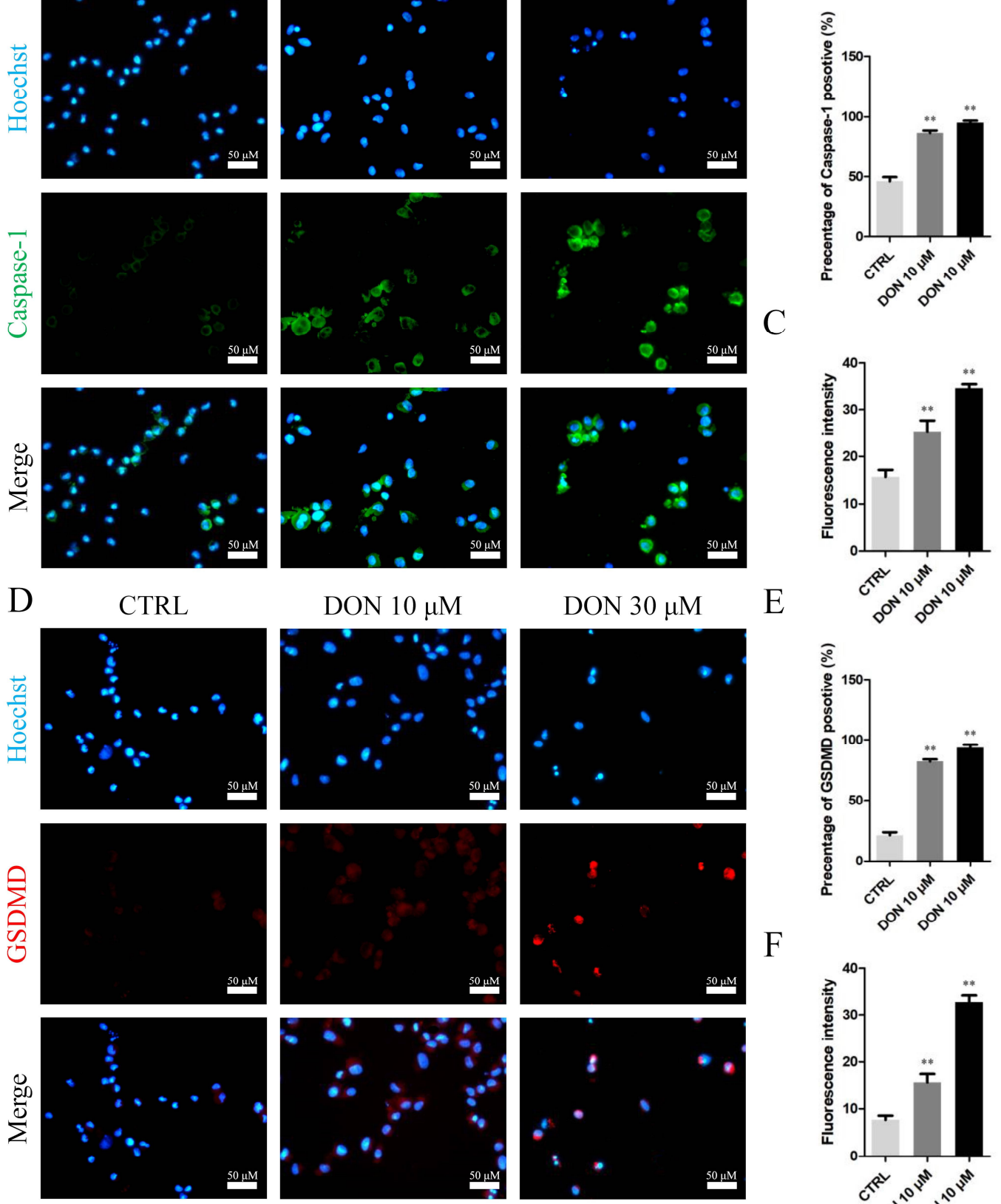

F

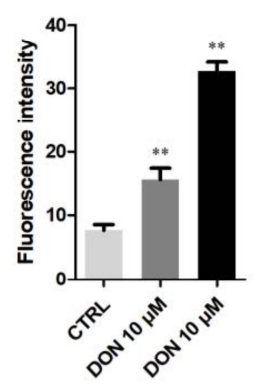

Figure 5. Immunofluorescence assay probing the expression of SC phosphor-Caspase1 (A) and GSDMD (D) proteins in the DON treatment groups. The percentages of positive cells $(\mathbf{B}, \mathbf{E})$ and fluorescence intensity $(\mathbf{C}, \mathbf{F})$ were analysed. Bar indicates $50 \mu \mathrm{m}$. Data are presented as the means \pm SD. ${ }^{* *} p<0.01$. 
A

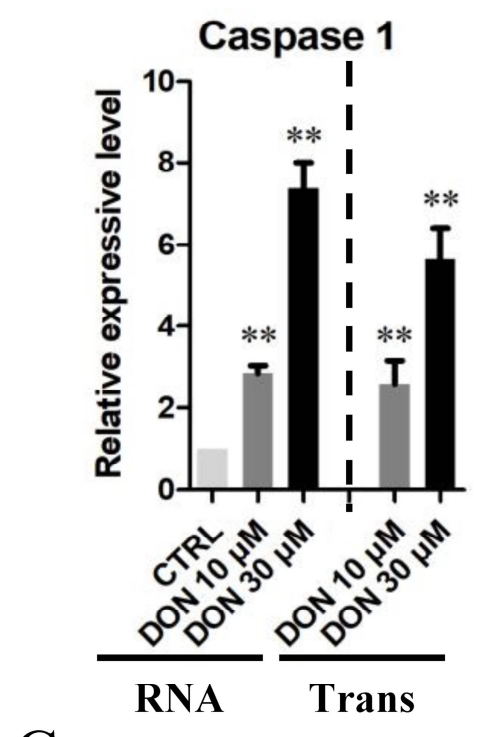

C

CTRL $10 \mu \mathrm{M} 30 \mu \mathrm{M}$

B

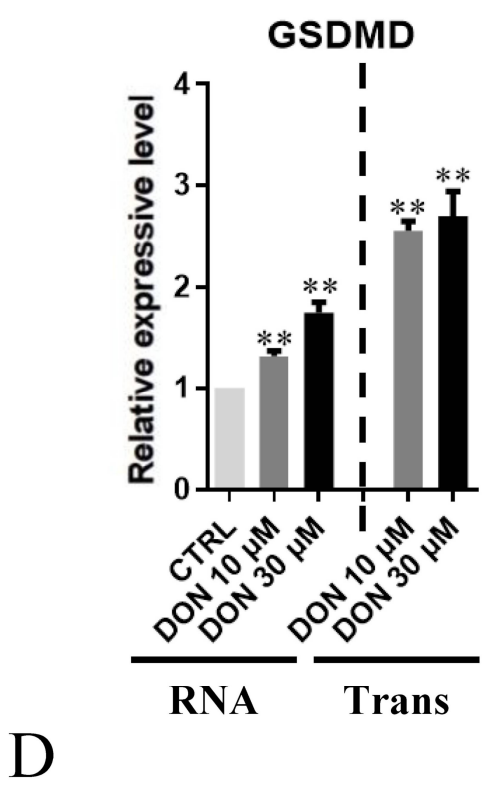

CTRL $10 \mu \mathrm{M} \quad 30 \mu \mathrm{M}$

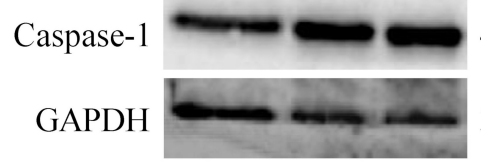

45 KDa GSDMD-N

$-32 \mathrm{KDa}$

$37 \mathrm{KDa}$ GAPDH

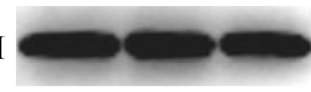

$37 \mathrm{KDa}$

Caspase 1

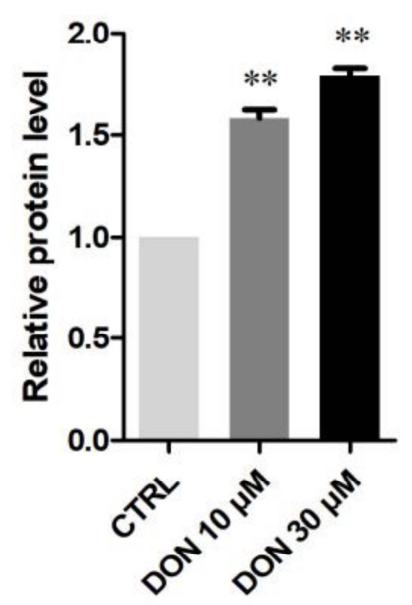

GSDMD-N

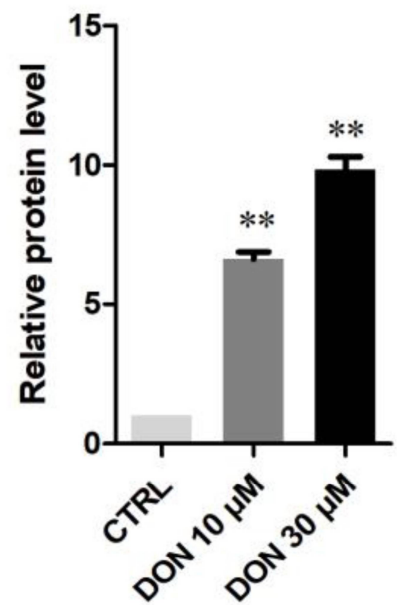

Figure 6. DON exposure affects the mRNA and protein abundance levels of pyroptosis-related genes in cultured Equus asinus SCs. (A) Quantitative RT-PCR for Caspase1 transcription factors. The mRNA levels of the genes were normalised to the GAPDH gene. (B) Quantitative RT-PCR for GSDMD transcription factors. The mRNA levels of the genes were normalised to the GAPDH gene. (C) Protein levels of Caspase1/GAPDH by Western blot. (D) Protein levels of GSDMD-N/GAPDH by Western blot. The protein levels were normalised to GAPDH. The exposure time was $50 \mathrm{~s}$. The results are presented as the means $\pm \mathrm{SD}$. All experiments were repeated at least three times. ${ }^{* *} p<0.01$. 

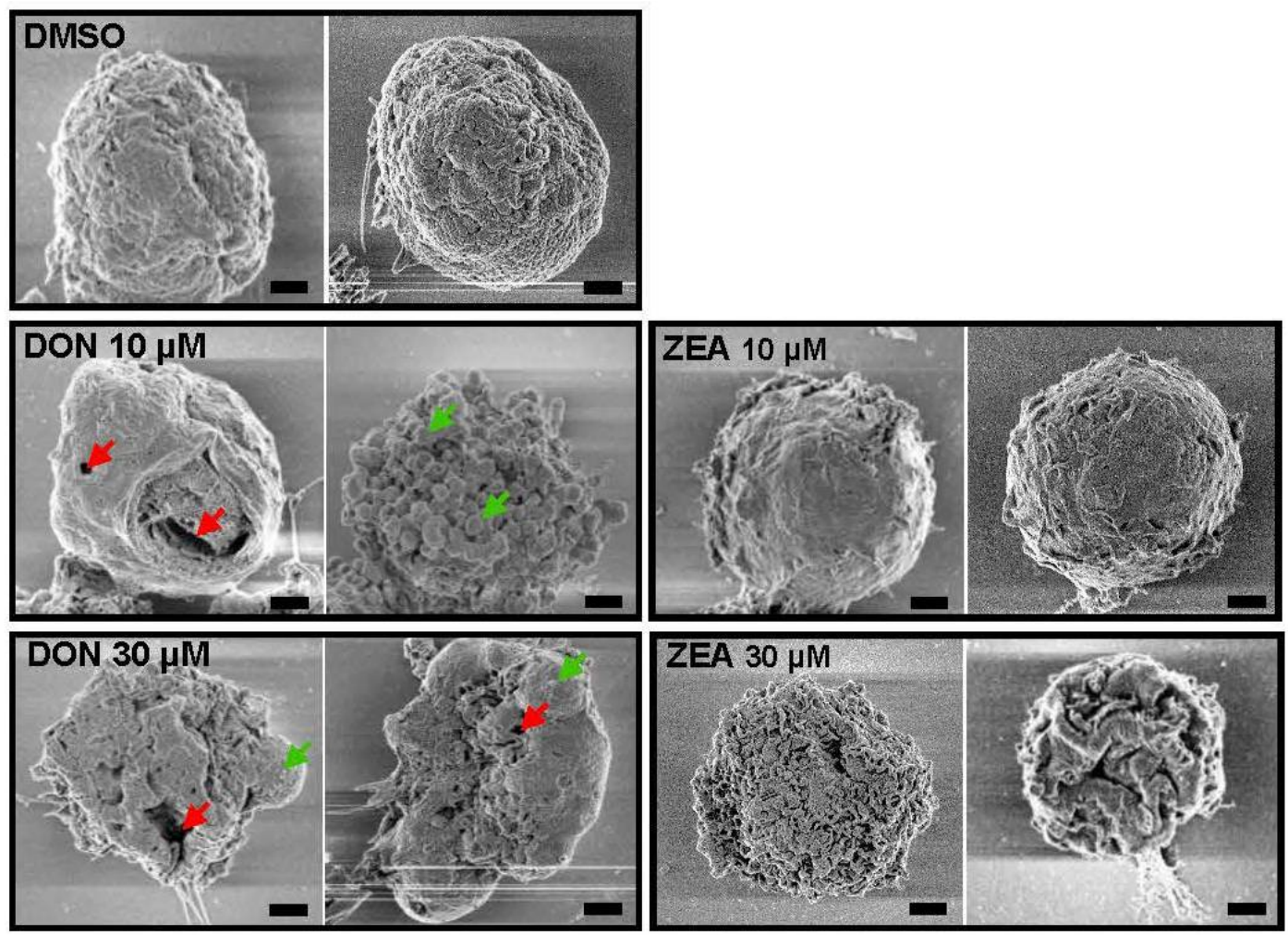

Figure 7. Representative scanning electron microscopy images of SCs treated with $10 \mu \mathrm{M}$ and $30 \mu \mathrm{M}$ DON and ZEA. Red arrows indicate membrane perforation, and green arrows indicate the apoptotic body-like cell protrusions. Bar indicates $1.0 \mu \mathrm{m}$ in the DMSO, $10 \mu \mathrm{M}$ and $30 \mu \mathrm{M}$ ZEA groups. Bar indicates $1.5 \mu \mathrm{m}$ in the $10 \mu \mathrm{M}$ and $30 \mu \mathrm{M}$ DON groups.

The results of the $10 \mu \mathrm{M}$ DON and $30 \mu \mathrm{M}$ ZEA analyses showed that DEGs were remarkably enriched in the oxidation-reduction process, PI3K-AKT signalling pathway and Ras signalling pathway (Figure 12A,D,G). Exposure to $10 \mu \mathrm{M}$ and $30 \mu \mathrm{M}$ DON (Figure 12B,E) and ZEA (Figure 12C,F) significantly downregulated the mRNA abundance and protein levels of PRDX4 genes in SCs, respectively. The number of PRDX4-positive cells was remarkably reduced in the $10 \mu \mathrm{M}$ and $30 \mu \mathrm{M}$ DON exposure groups (Figure 13A-C), while there was a significantly decreased number of PRDX4-positive cells in the $30 \mu \mathrm{M}$ ZEA treatment group (Figure 13D-F). In addition, the number of NOX1-positive cells remarkably increased in the $10 \mu \mathrm{M}$ and $30 \mu \mathrm{M}$ DON (Figure S2A-C) and ZEA (Figure S2D-F) exposure groups.

Our RT-qPCR and Western blot results indicated that SCs under $10 \mu \mathrm{M}$ and $30 \mu \mathrm{M}$ DON treatment exhibited significantly lower MSH6 mRNA and protein levels than those under the control treatment $(p<0.05$ or $p<0.01$ ) (Figure 14A,D), whereas the CDK1 and CCNB2 genes were significantly upregulated in the $10 \mu \mathrm{M}$ and $30 \mu \mathrm{M}$ ZEA exposure groups (Figure 14B,C,E,F). We conducted more RT-qPCR to evaluate the expression of different transcripts in the pathways of SCs among the control, DON and ZEA treatments (Figure S3). 
A
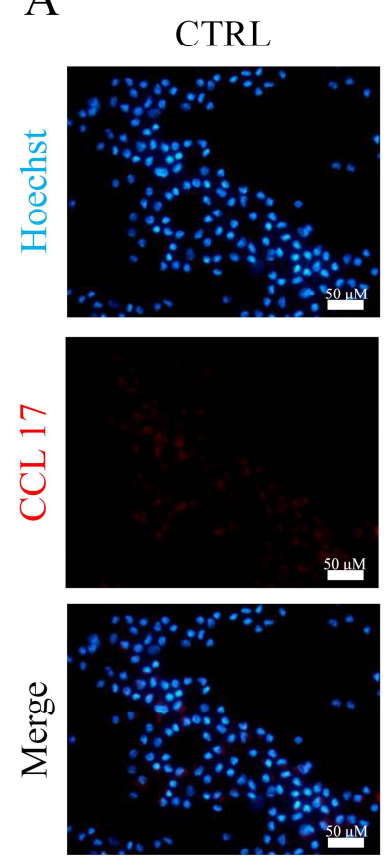

D
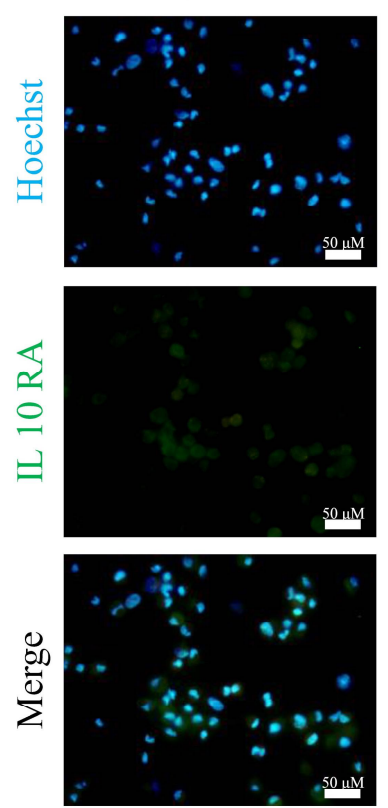

DON $10 \mu \mathrm{M}$
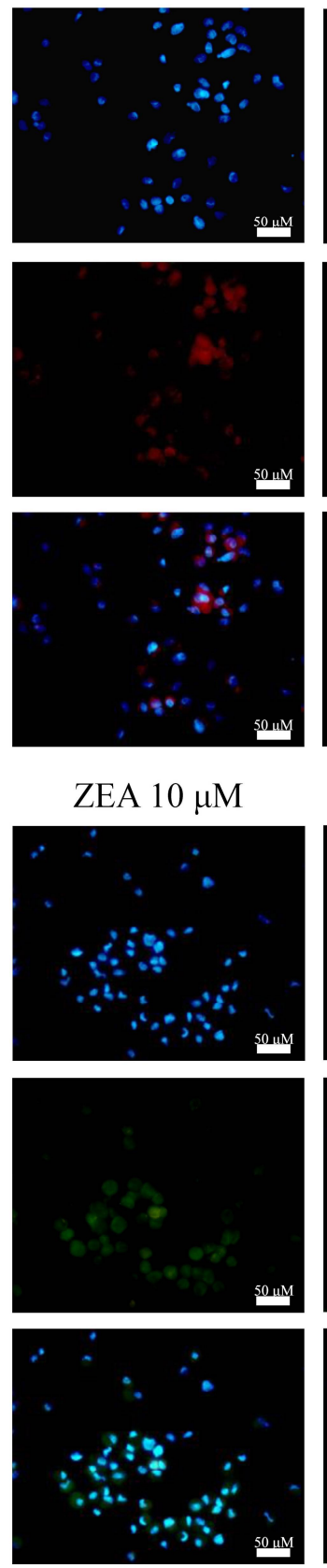

B
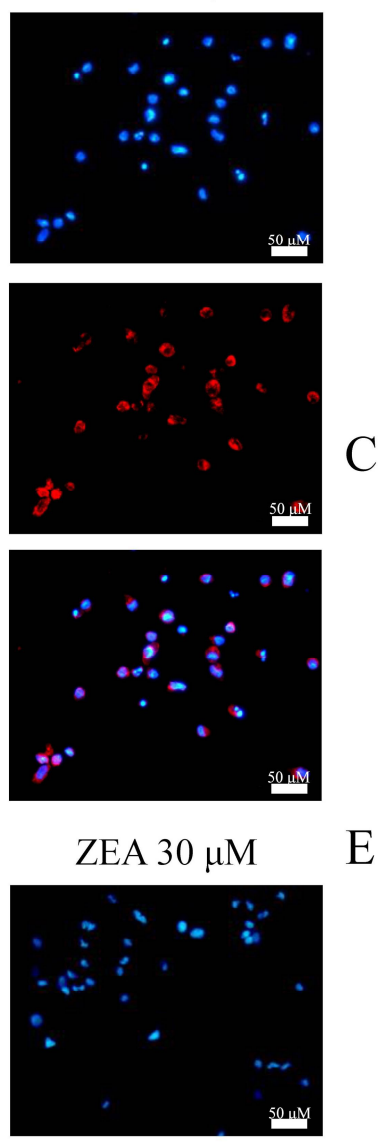

E
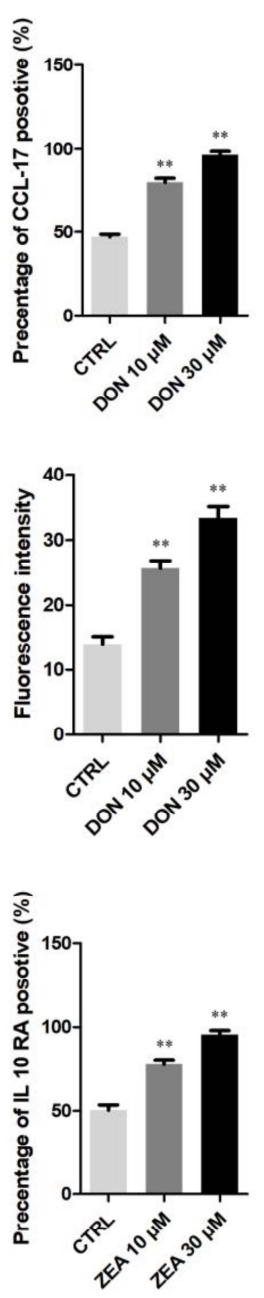

$\mathrm{F}$

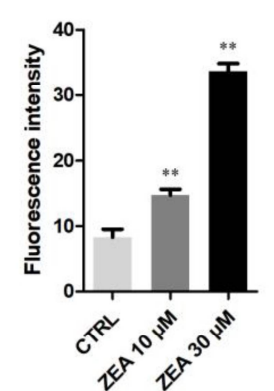

Figure 8. Immunofluorescence assay probing the expression of SC phosphor-CCL17 (A), and IL10RA (D) proteins in the DON and ZEA treatment groups. The percentages of positive cells $(\mathbf{B}, \mathbf{E})$ and fluorescence intensity $(\mathbf{C}, \mathbf{F})$ were analysed. Bar indicates $50 \mu \mathrm{m}$. Data are presented as the means \pm SD. ${ }^{* *} p<0.01$. 
A

\section{17}
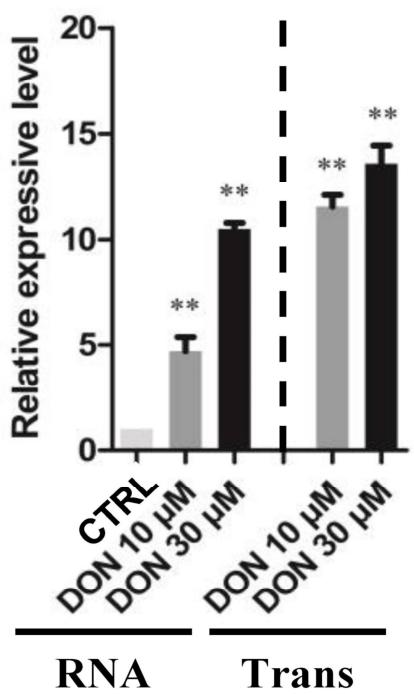

C

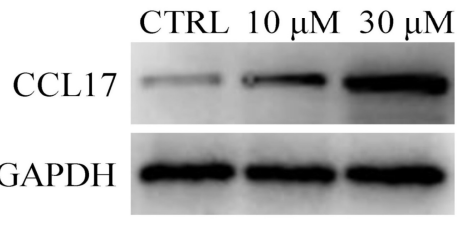

CCL 17

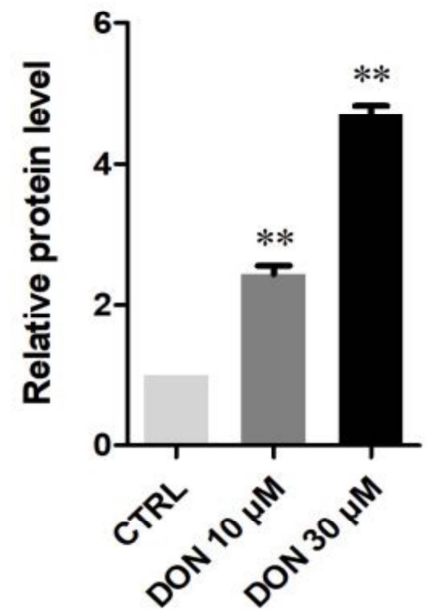

B

\section{IL 10 RA}

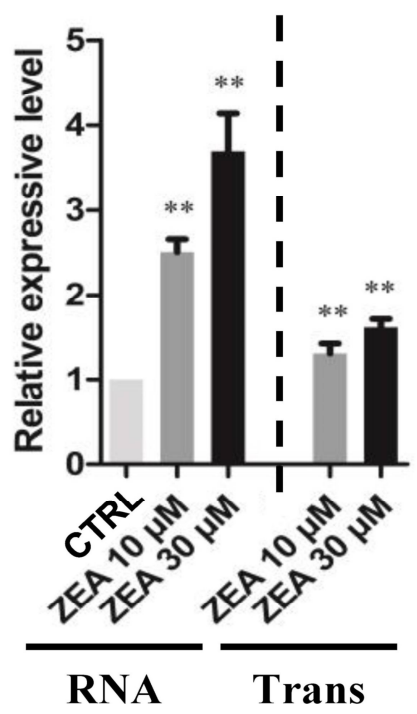

D

CTRL $10 \mu \mathrm{M} 30 \mu \mathrm{M}$

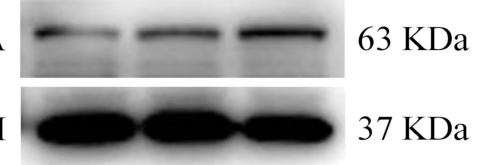

IL 10 RA

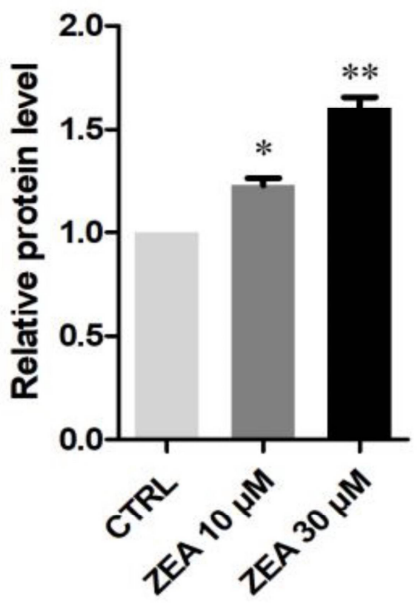

Figure 9. DON and ZEA exposure affects the mRNA and protein abundance levels of inflammation-related genes in cultured Equus asinus SCs. (A) Quantitative RT-PCR for the CCL17 transcription factors. (B) Quantitative RT-PCR for the IL10RA transcription factors. The mRNA levels of the gene were normalised to the GAPDH gene. (C) Protein levels of CCL17/GAPDH by Western blot. (D) Protein levels of IL10RA/GAPDH by Western blot. The protein levels were normalised to GAPDH. The exposure time was $50 \mathrm{~s}$. The results are presented as the mean $\pm \mathrm{SD}$. All experiments were repeated at least three times. ${ }^{*} p<0.05 ;{ }^{* *} p<0.01$. 
A

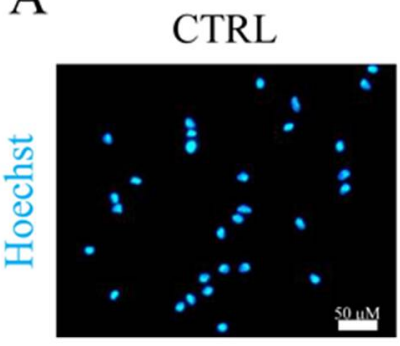

\section{DON $10 \mu \mathrm{M}$}
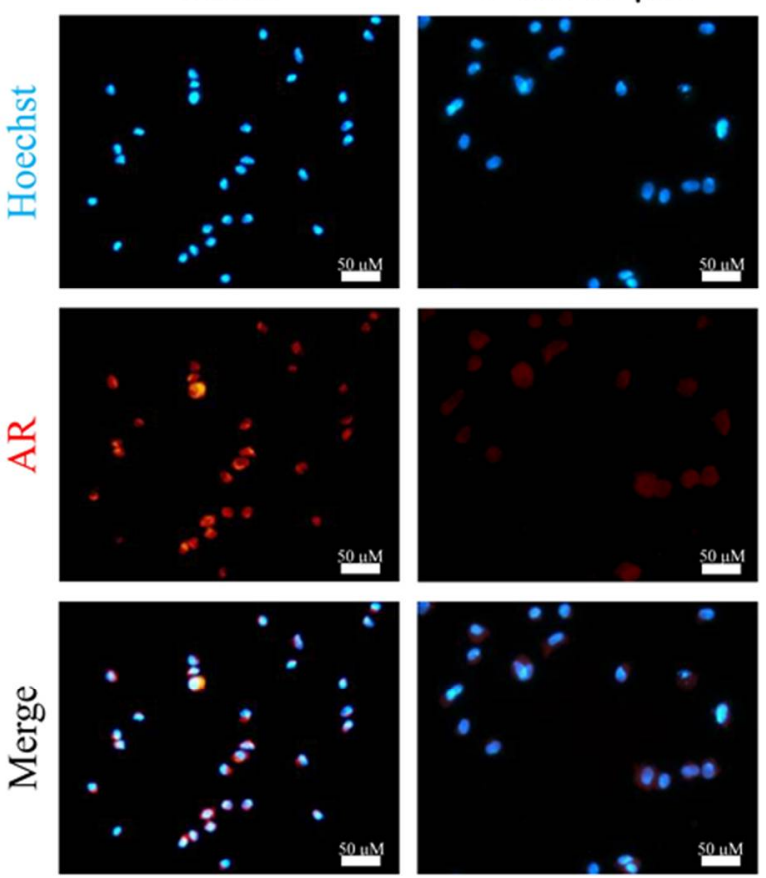

D
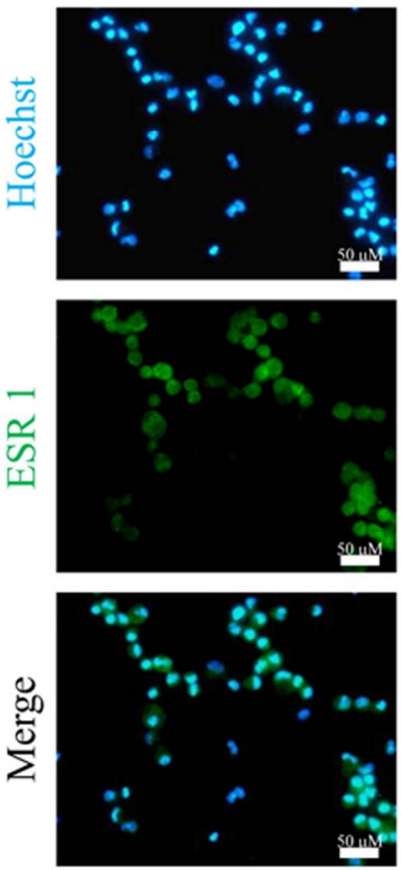
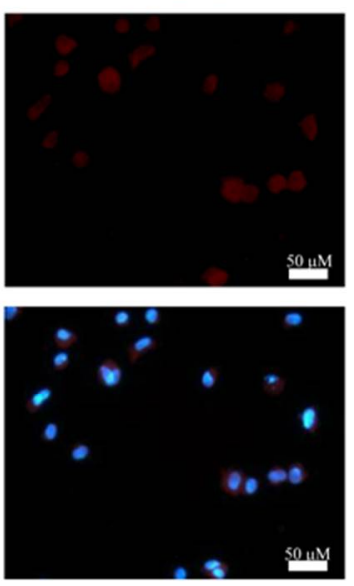

ZEA $10 \mu \mathrm{M}$
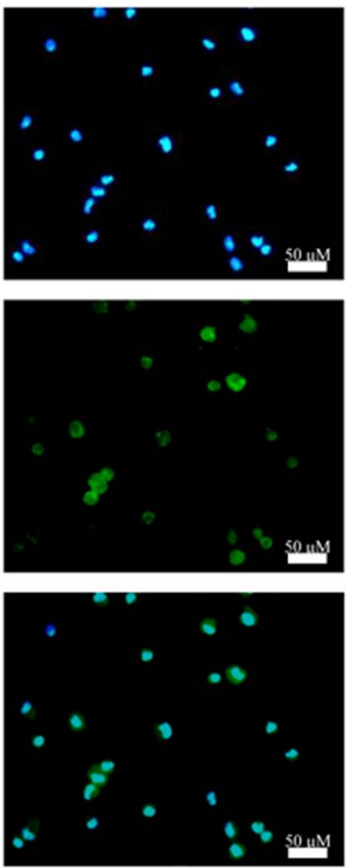

DON $30 \mu \mathrm{M}$
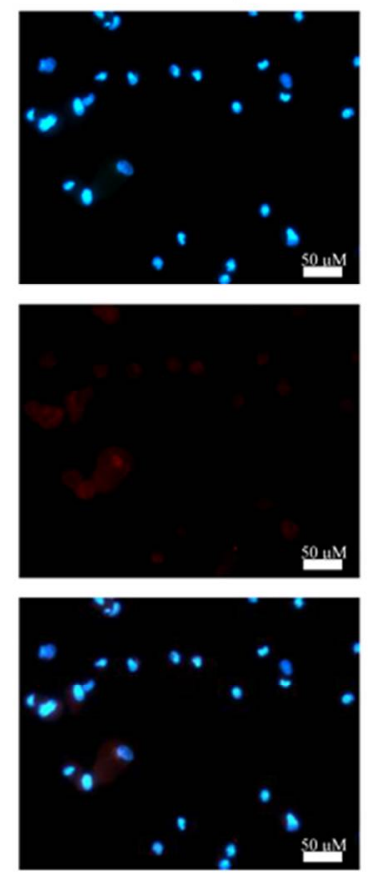

ZEA $30 \mu \mathrm{M}$
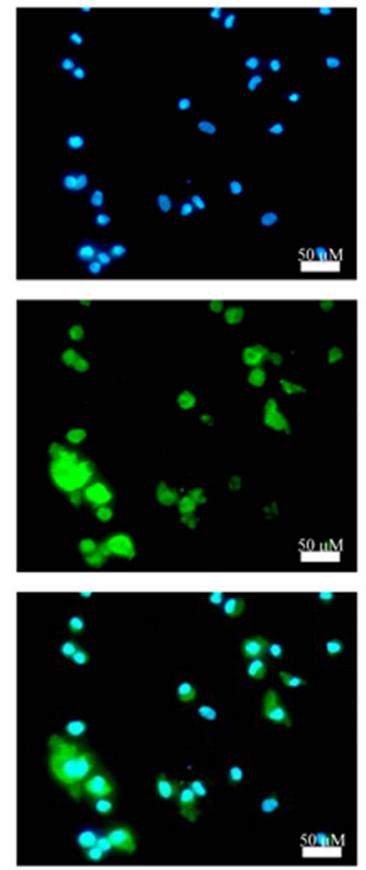

B

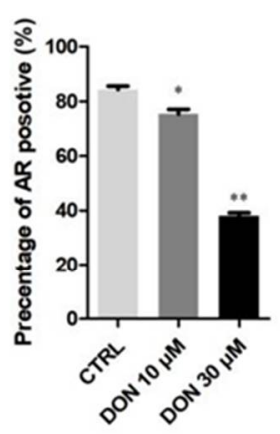

C

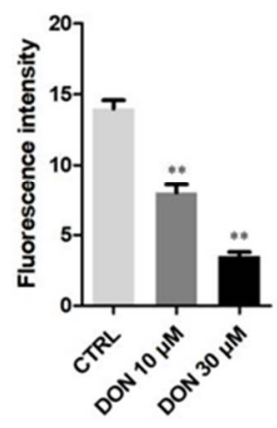

E

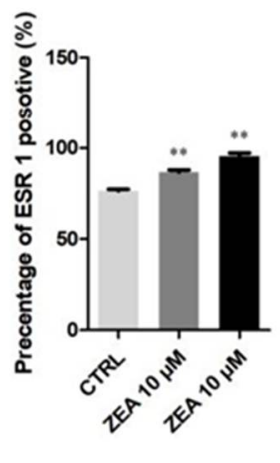

F

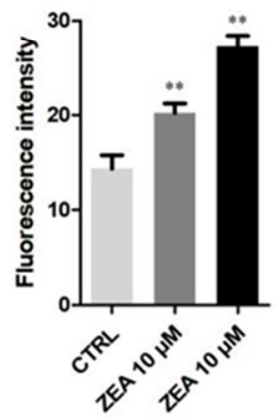

Figure 10. Immunofluorescence assay probing the expression of phosphor-AR (A) and ESR1 (D) proteins in SCs in the DON and ZEA treatment groups. The percentages of positive cells $(\mathbf{B}, \mathbf{E})$ and fluorescence intensity $(\mathbf{C}, \mathbf{F})$ were analysed. Bar indicates $50 \mu \mathrm{m}$. Data are presented as the means $\pm \mathrm{SD}$. ${ }^{*} p<0.05 ;{ }^{* *} p<0.01$. 
A

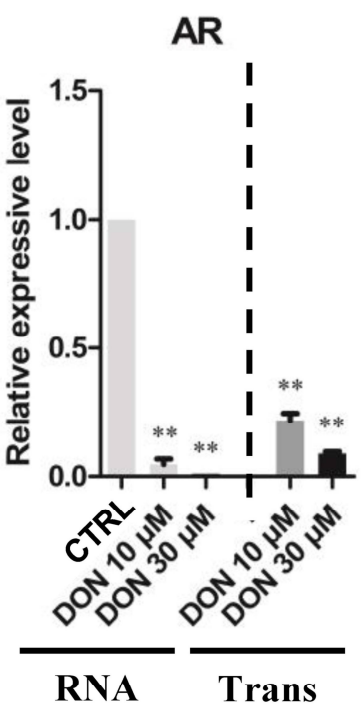

B

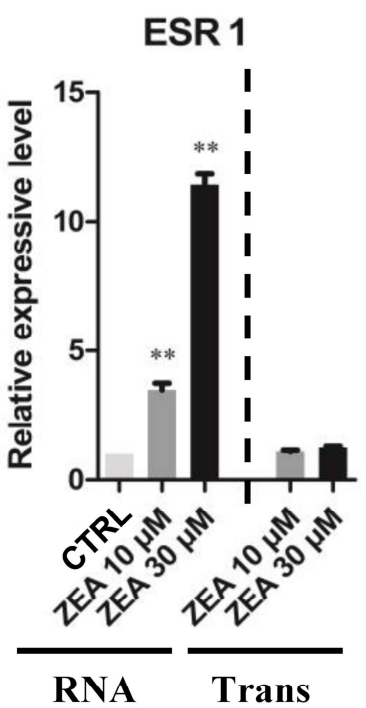

$\mathrm{C}$

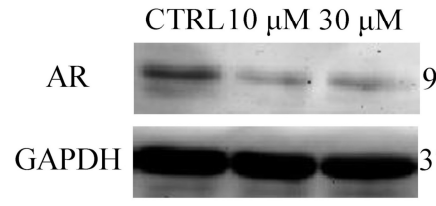

AR

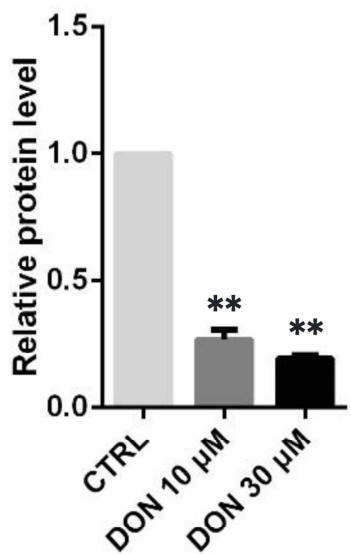

D

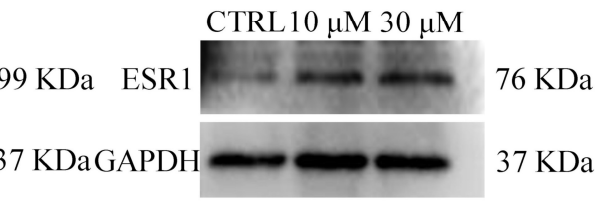

ESR 1

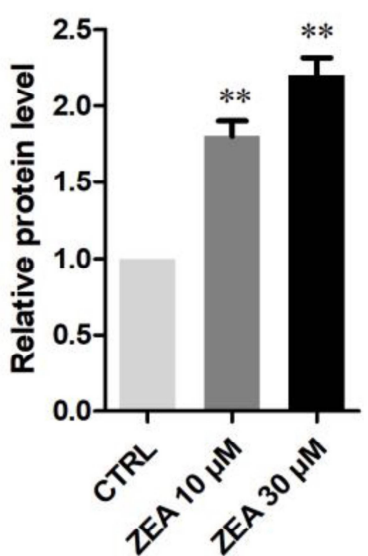

Figure 11. DON and ZEA exposure affects the mRNA and protein abundance of endocrine-related genes in cultured Equus asinus SCs. (A) Quantitative RT-PCR for the AR transcription factors. (B) Quantitative RT-PCR for the ESR transcription factors. The mRNA levels of the genes were normalised to the GAPDH gene. (C) Protein levels of $A R / G A P D H$ by Western blot. (D) Protein levels of ESR/GAPDH by Western blot. The protein levels were normalised to GAPDH. The exposure time was $50 \mathrm{~s}$. The results are presented as the means \pm SD. All experiments were repeated at least three times. ${ }^{*} p<0.01$. 
A

DON $10 \mu \mathrm{M}$ VS. CTRL ZEA $30 \mu \mathrm{M}$ VS. CTRL

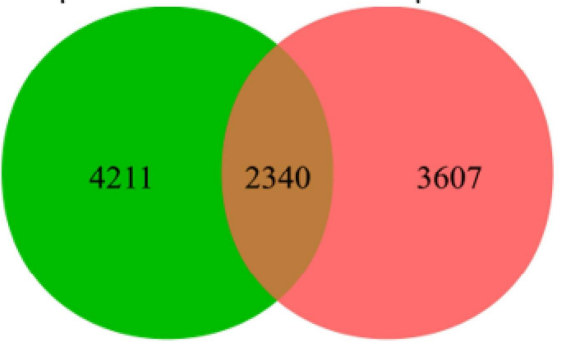

D

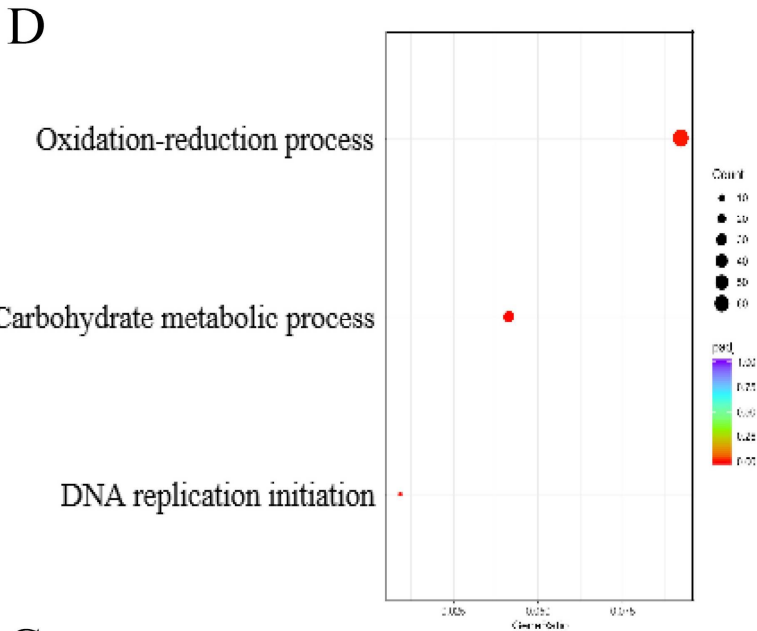

G

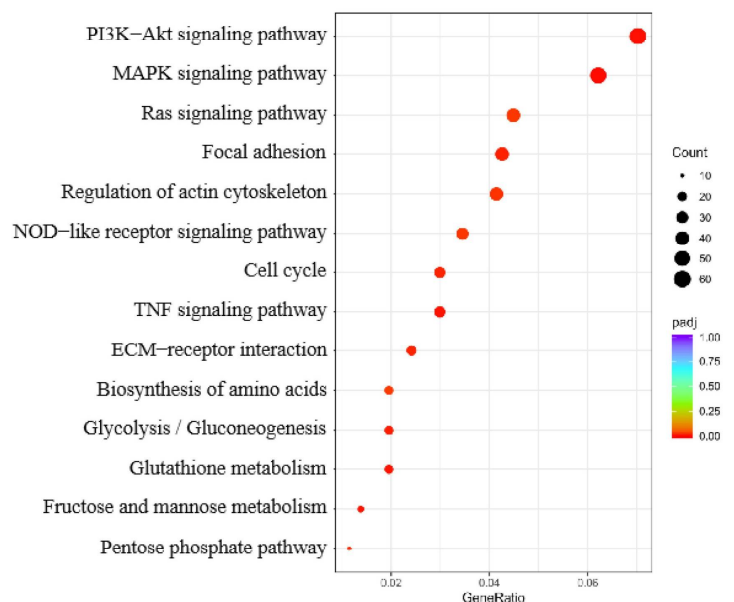

B

PRDX 4

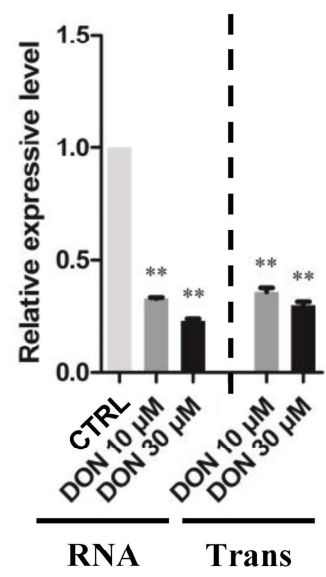

E

CTRL $10 \mu \mathrm{M} 30 \mu \mathrm{M}$

PRDX 4

GAPDH

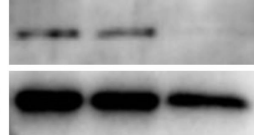

PRDX 4

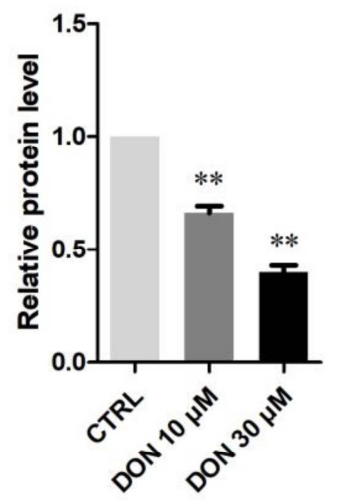

C

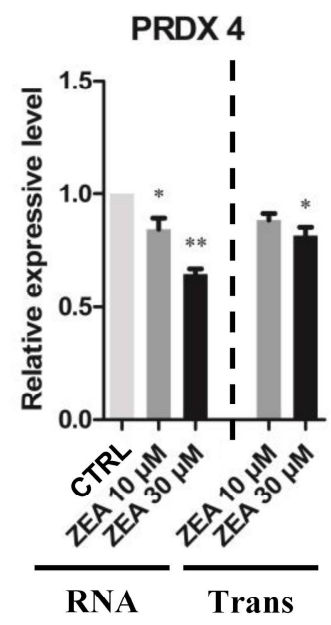

F

CTRL $10 \mu \mathrm{M} 30 \mu \mathrm{M}$

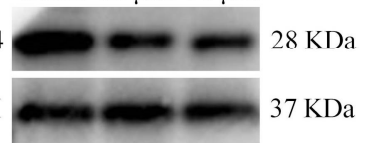

PRDX 4

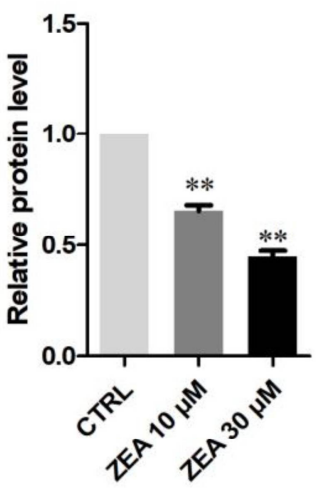

Figure 12. Gene expression of RNA-seq analysis and protein verification between the $10 \mu \mathrm{M} D O N$ - and $30 \mu \mathrm{M} Z \mathrm{ZEA}$ treated groups. (A) Venn diagram showing DEGs in SCs exposed to $10 \mu \mathrm{M}$ DON and $30 \mu \mathrm{M}$ ZEA. (B,C) Quantitative RT-PCR for the PRDX4 transcription factors in SCs treated with DON and ZEA. (D,G) GO and KEGG enrichment of 2340 DEGs in Equus asinus SCs exposed to $10 \mu \mathrm{M}$ DON and $30 \mu \mathrm{M}$ ZEA. (E,F) The protein levels of PRDX4/GAPDH by Western blot in DON and ZEA treatment groups. The protein levels were normalised to GAPDH. The exposure time was $50 \mathrm{~s}$. The results are presented as the means $\pm \mathrm{SD}$. All experiments were repeated at least three times. ${ }^{*} p<0.05 ;{ }^{* *} p<0.01$. 
A

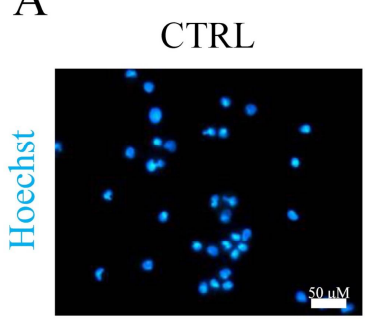

DON $10 \mu \mathrm{M}$

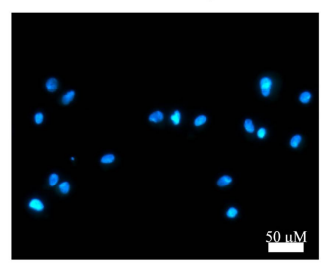

DON $30 \mu \mathrm{M}$
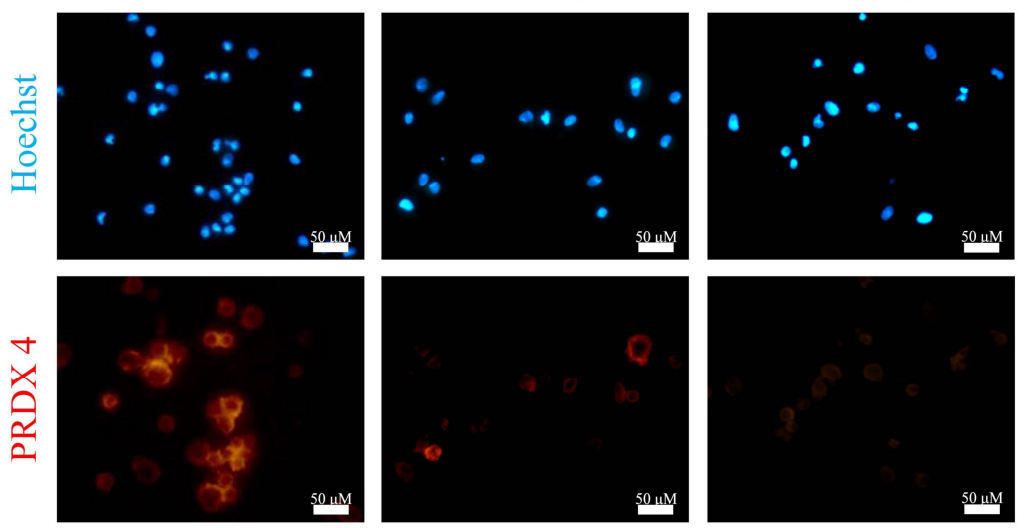

B
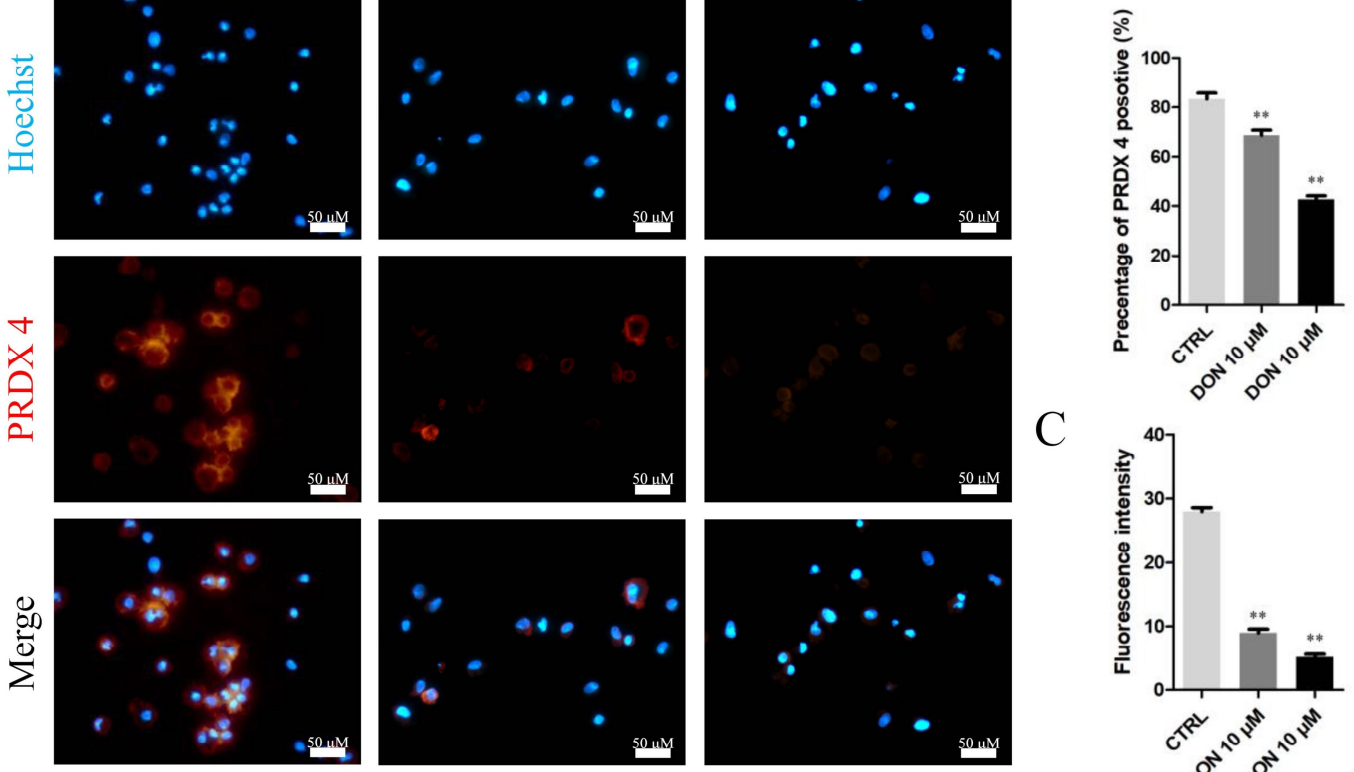

D CTRL

ZEA $10 \mu \mathrm{M}$

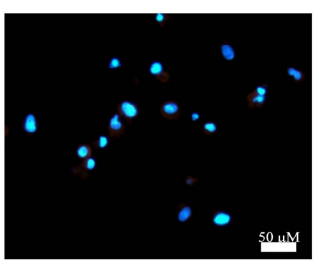

C
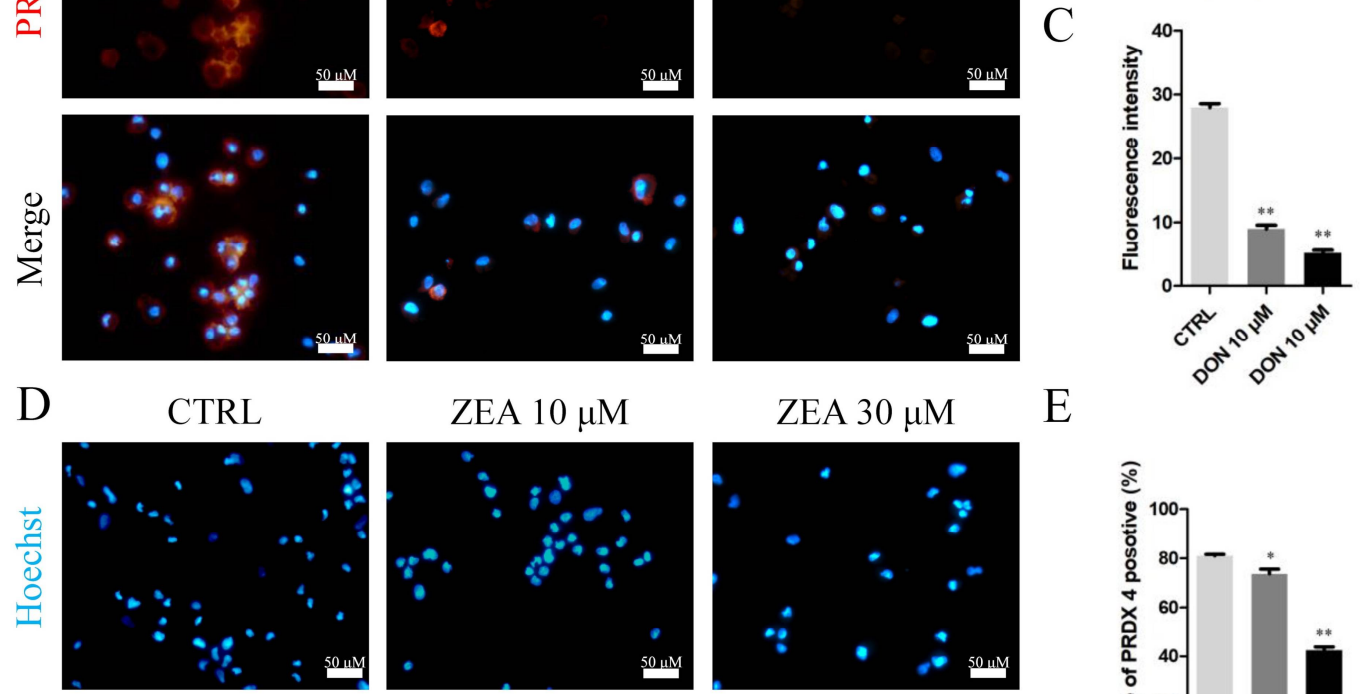

ZEA $30 \mu \mathrm{M}$

E
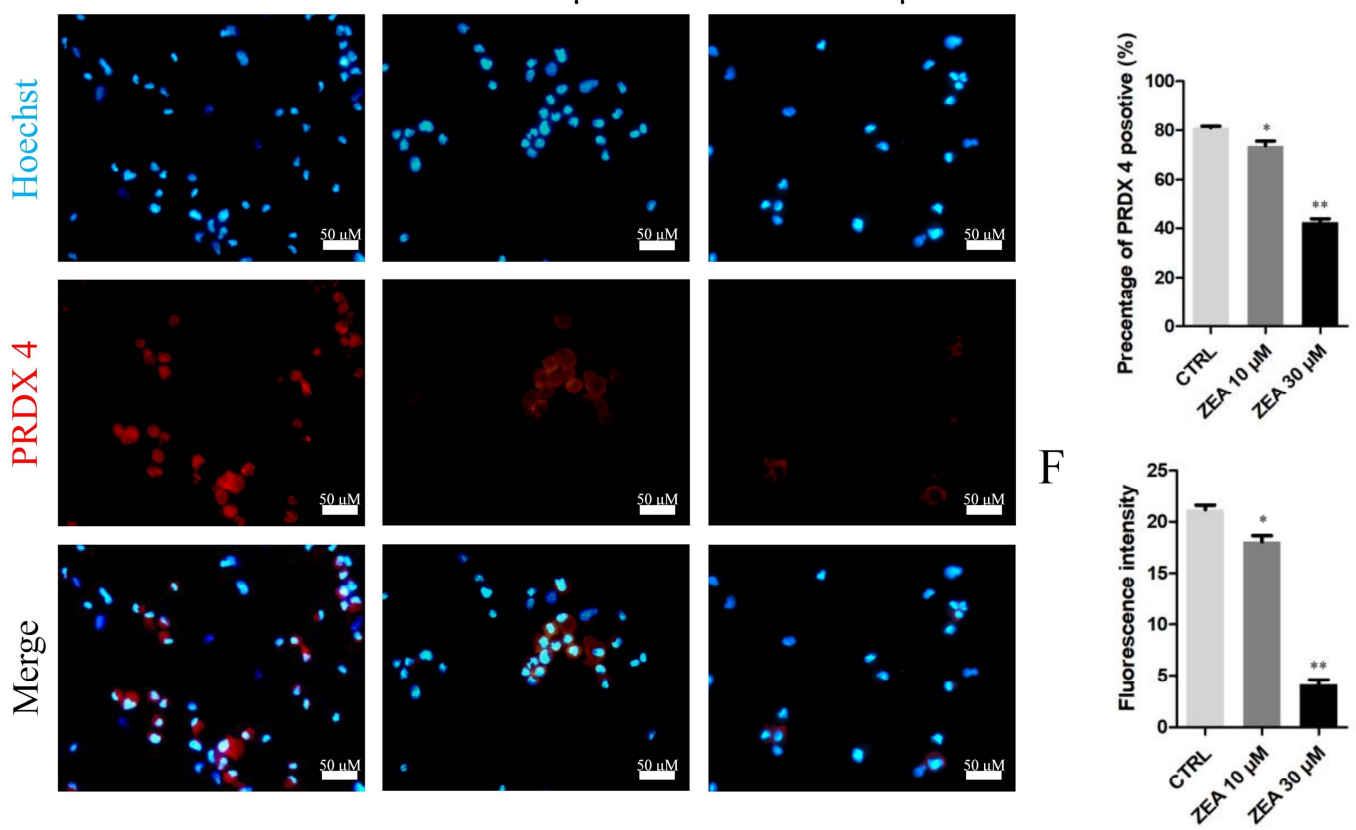

Figure 13. Immunofluorescence assay probing the expression of SC phosphor-PRDX4 proteins in the DON (A) and ZEA (D) treatment groups. The percentages of positive cells $(\mathbf{B}, \mathbf{E})$ and fluorescence intensity $(\mathbf{C}, \mathbf{F})$ were analysed. Bar indicates 50 $\mu \mathrm{m}$. Data are presented as the means $\pm \mathrm{SD} .{ }^{*} p<0.05 ;{ }^{* *} p<0.01$. 
A

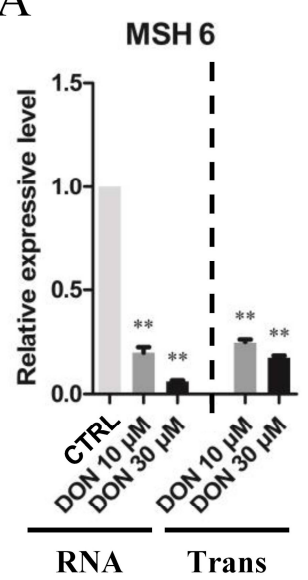

D

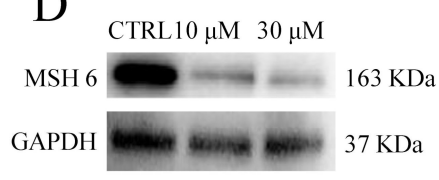

MSH 6

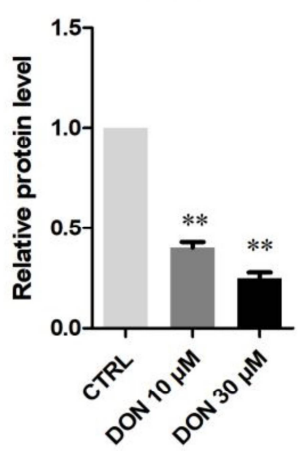

B

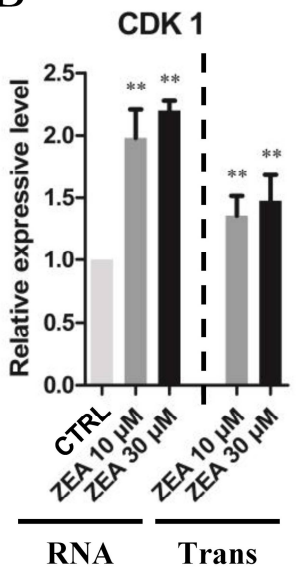

E

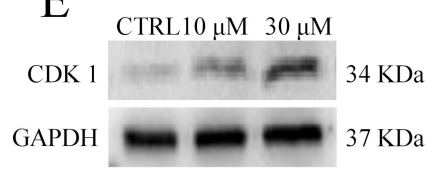

CDK 1

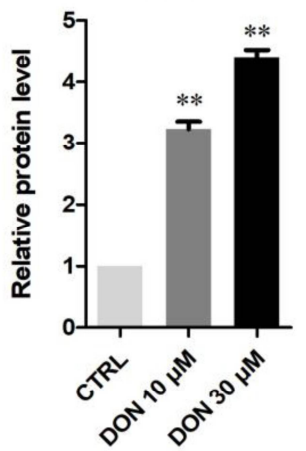

C

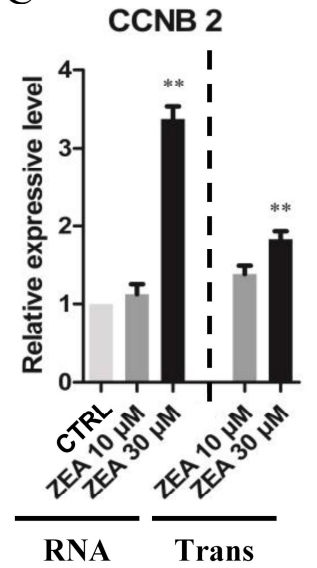

F

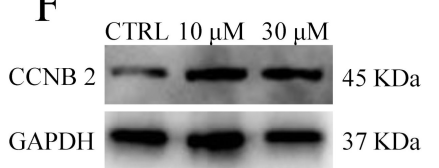

CCNB 2

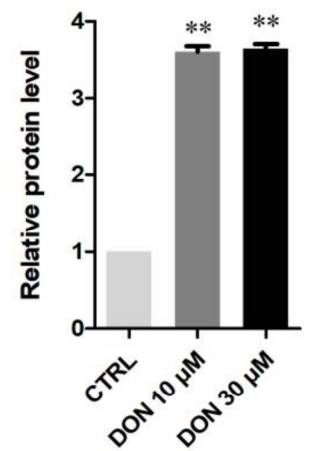

Figure 14. DON and ZEA exposure affected the mRNA and protein abundance levels of tumorigenesis-related genes in cultured GCs. (A-C) Quantitative RT-PCR for MSH6 in the DON treatment group, CDK1 and CCNB2 in the ZEA exposure groups. The mRNA levels of all genes were normalised to the GAPDH gene in SCs. (D-F) The protein levels of MSH6/GAPDH in the DON treatment group, CDK1/GAPDH and CCNB2/GAPDH in the ZEA treatment group were detected by Western blot. The protein levels were normalised to GAPDH. The results are presented as the means $\pm \mathrm{SD}$. All experiments were repeated at least three times. ${ }^{* *} p<0.01$.

\section{Discussion}

Fusarium mycotoxins have been implicated in poor reproductive performance in domestic animals, including male Equus asinus [5,7,8,32,39,45-47]. In vitro reports with DON or ZEA demonstrated that mycotoxins are able to directly affect the reproductive [47-50], endocrine [51,52], and immune systems [53-55], as well as inheritance [32,45]. Previous research demonstrated that the function of SCs is essential in the processes of normal spermatogenesis and testis development [30-32]. Moreover, present findings suggested that individual or mixtures of Fusarium toxins had cytotoxic effects on porcine Sertoli and Leydig cells [56,57]. However, additive effects were not always observed for the mixtures of Fusarium toxins [56,58-60]. The present study was designed to investigate the effects of mycotoxin DON and ZEA treatment on pyroptosis, viability, the cell cycle, cell secretion, and cell inflammation in cultured SCs. We used immature SCs cultured in vitro and RNA-seq methods to compare the toxic effects of DON and ZEA to Equus asinus SCs. This is the first study to describe the differences in the transcriptomes of SCs between DON and ZEA exposure. Our results provide a basic database for mycotoxins in SC studies of Equus asinus. 
Pyroptosis is a newly discovered type of regulated necrotic cell death induced by inflammasomes, such as Caspase1 and Caspase11 (in mouse cells) [61,62]. Both Caspase1 and Caspase11 can induce pyroptosis by processing Gasdermin D (GSDMD), yielding an Nterminal fragment that forms pores on the plasma membrane, leading to cell death $[63,64]$. Unlike apoptosis, pyroptosis is a highly specific type of inflammation that has been proven to be strongly associated with cancer [65]. Our results showed that the mRNA and protein expression levels of Caspase1 and GSDMD-N in Equus asinus SCs remarkably increased upon exposure to $10 \mu \mathrm{M}$ DON. Moreover, representative scanning electron microscopy images indicated that SCs treated with DON undergo membrane perforation and produce apoptotic body-like cell protrusions prior to plasma membrane rupture [44]. Some SCs also showed initial changes in the substructure of the plasma membrane characterised by focal disappearance of membrane structure and partial loss of continuity, as described for necrotic cells [66]. These results indicated that the canonical pyroptosis pathways in SCs had been activated and that SCs possessed the typical pyroptosis appearance [67] and severe cellular inflammation.

Furthermore, the mRNA abundance and protein levels of CCL17 in the SCs remarkably increased after exposure to DON. High levels of CCL17 have been found in SCs in seminoma tumours [68]. Therefore, DON treatment may promote the expression of the hallmarks of tumour formation given its effect on pyroptosis-related genes and CCL17 expression. ZEA is a non-steroidal oestrogenic mycotoxin. In contrast, depending on the molecular structure, ZEA may have binding affinities to oestrogen receptors and, therefore, mimic oestrogenic effects in SCs. We found that exposure to $30 \mu \mathrm{M}$ ZEA significantly increased the mRNA abundance and protein levels of ESR1, ESR2, and IL10RA in SCs. This phenomenon indicates that exposure to ZEA may lead to inflammation and affect the endocrine function of SCs. A total of 6551 and 803 genes were differentially expressed in SCs under the control of $10 \mu \mathrm{M}$ DON and ZEA treatment. Furthermore, we identified 8605 and 5947 DEGs in the SCs under $30 \mu \mathrm{M}$ DON and ZEA treatment, respectively. In summary, the above results suggest that DON treatment may lead to pyroptosis and promote the expression of oncogenes, while exposure to ZEA results in inflammation and affects endocrine disruption in cells. Furthermore, Equus asinus SCs are more sensitive to DON exposure than SCs treated with the same dose of ZEA.

In addition, bioinformatics analyses found that $P R D X 4$ and cell oxidation-reduction related genes were influenced in SCs exposed to $10 \mu \mathrm{M}$ DON and $30 \mu \mathrm{M}$ ZEA. Our results indicated that DON might have stronger oxidative toxicity than ZEA in Equus asinus SCs. Moreover, several studies have demonstrated that MSH6 (an important component of the mismatch repair system) is a tumour-related factor that can affect tumorigenesis, proliferation, migration, and invasion effects [69]. It is well known that suppression of MSH6 is associated with a variety of tumours [70,71]. Interestingly, it was found in this study that $10 \mu \mathrm{M}$ DON exposure significantly decreased the mRNA and protein levels of MSH6 in SCs. Therefore, exposure to $10 \mu \mathrm{M} \mathrm{DON}$ may be potentially mutagenic and carcinogenic. Several studies have indicated that CCNB2 is a regulatory protein involved in mitosis, and its product can combine with $C D K 1$ to form a maturation-promoting factor [72-75]. CCNB2 overexpression can result in uncontrolled cell growth [76,77].

In this study, we found that exposure to $30 \mu \mathrm{M}$ ZEA remarkably upregulated the mRNA and protein abundance of CCNB2 in SCs. In contrast, exposure to $10 \mu \mathrm{M}$ ZEA resulted in CDK1 overexpression in SCs. These results suggest that $30 \mu \mathrm{M}$ ZEA treatment may promote the expression of oncogenes in SCs. Furthermore, exposure to $10 \mu \mathrm{M} D O N$ resulted in IL32 and NOX1 gene overexpression, while the AR, AIG1, MCM6, and POLD1 genes were suppressed in SCs. In addition, $30 \mu \mathrm{M}$ ZEA treatment led to PFKM, NOX1, and ESR2 gene overexpression in the cells. In our experiments, we observed a suppressive effect on the mRNA abundance of the $A R$ gene of SCs at concentrations of $10 \mu \mathrm{M}$ and $30 \mu \mathrm{M}$ DON treatment, while there was a stimulatory effect on the ESR1 and ESR2 genes of SCs under $30 \mu \mathrm{M}$ ZEA exposure. The above results validated that DON and ZEA had differential toxic patterns in Equus asinus SCs. Additionally, the exact mechanisms by 
which DON or ZEA changes cell secretion in Equus asinus SCs remain the subject of further investigation.

We also found proapoptotic effects of DON and ZEA using flow cytometry and TUNEL-positive analysis. A significant reduction in the SCs was observed at toxic concentrations of both mycotoxins. The results demonstrate that the mycotoxins DON and ZEA can stimulate cell apoptosis in Equus asinus SCs. Both mycotoxins seem to transmit their molecular effects by influencing the MAPK signalling cascades and the protein kinase Akt, which could result in translation anomalies. However, it can be assumed that DON and ZEA modulate the process of translation at different molecular levels. Whereas DON mainly had an impact on pyroptosis and androgen disruption and therefore on the biological activity of the Caspase1, GSDMD, CCL17, AR, and AIG1 genes, ZEA increased the abundance of IL 10 RA, CDK1, PFKM, NOX1, and specific bands of the ESR1 and ESR2 genes. Thus, DON and ZEA exerted toxic effects on SCs in a different manner. Further investigations are required to obtain more information about specific signalling cascades that transmit the toxicity of DON and ZEA in Equus asinus SCs.

Supplementary Materials: The following are available online at https://www.mdpi.com/article/10 .3390 / cells10081898/s1, Figure S1: DON and ZEA exposure increasing apoptosis rate in cultured SCs. SCs were stained blue with Hoechst 33342 solution. TUNEL assay was performed using immunostaining. (A) Immunofluorescent staining of TUNEL and Hoechst33342 of DON treated SCs. Bar indicates $50 \mu \mathrm{m}$. (B) The percentages of TUNEL positive SCs exposed to DON. (C) Immunofluorescent staining of TUNEL and Hoechst33342 of ZEA treated SCs. Bar indicates $50 \mu \mathrm{m}$. (D) The percentages of TUNEL positive SCs exposed to ZEA. The results are presented as mean $\pm \mathrm{SD}$. All experiments were repeated at least three times. $p<0.05 ;{ }^{*} p<0.01$. Figure S2: Immunofluorescence assay probing the expression of SCs phosphor- NOX1 proteins in DON (A) and ZEA (D) treatment groups. The percentages of positive cells $(\mathrm{B} / \mathrm{E})$ and fluorescence intensity $(\mathrm{C} / \mathrm{F})$ were analyzed respectively. Bar indicates $50 \mu \mathrm{m}$. Data are presented as means \pm SD. $p<0.05 ;{ }^{*} p<0.01$. Figure S3: DON and ZEA exposure affecting mRNA abundance of tumorigenesis related genes in cultured GCs. (A-E) Quantitative RT-PCR for IL32, AIG1, NOX1, MCM6, and POLD1 in DON treatment groups. (F-J) IL32A, ESR2, NOX1, PGK1, and PFKM in ZEA exposure groups. The mRNA levels of all genes were normalized to SCs GAPDH gene. The results are presented as mean $\pm \mathrm{SD}$. All experiments were repeated at least three times. $p<0.05 ;{ }^{*} p<0.01$.

Author Contributions: Conceptualisation, formal analysis, investigation, data curation, writingoriginal draft preparation, J.-L.S.; writing-review and editing, project administration, funding acquisition, G.-L.Z. All authors have read and agreed to the published version of the manuscript.

Funding: This research was funded by the National Natural Science Foundation of China, grant number 31902158; the Natural Science Foundation of Shandong Province, grant number ZR2019BC067; the Research Foundation for Advanced Talents of Qingdao Agricultural University, grant number 665/1119013 and the Research Foundation of E-Jiao efficiency, grant number 660/2418113.

Institutional Review Board Statement: The study was conducted according to the guidelines of the Declaration of Helsinki, and approved by the Ethics Committee of QINGDAO AGRICULTURAL UNIVERSITY (protocol code DEC 2020-019 and 5 November 2020).

Informed Consent Statement: Not applicable.

Data Availability Statement: Nine libraries from the three groups were sequenced, and 715,715,682 raw reads (GEO accession number: GSE172037) were uploaded to Gene Expression Omnibus (https: / / www.ncbi.nlm.nih.gov/geo/, accessed on 25 July 2021).

Acknowledgments: The authors are grateful to Paul W. Dyce for his suggestions on the manuscript.

Conflicts of Interest: The authors declare no conflict of interest. 


\section{References}

1. Wu, Q.; Lohrey, L.; Cramer, B.; Yuan, Z.; Humpf, H.U. Impact of physicochemical parameters on the decomposition of deoxynivalenol during extrusion cooking of wheat grits. J. Agric. Food Chem. 2011, 59, 12480-12485. [CrossRef]

2. Pinton, P.; Oswald, I.P. Effect of deoxynivalenol and other Type B trichothecenes on the intestine: A review. Toxins 2014, 6, 1615-1643. [CrossRef]

3. Doll, S.; Danicke, S. The Fusarium toxins deoxynivalenol (DON) and zearalenone (ZON) in animal feeding. Prev. Vet. Med. 2011, 102, 132-145. [CrossRef] [PubMed]

4. Mousavi Khaneghah, A.; Fakhri, Y.; Sant'Ana, A.S. Impact of unit operations during processing of cereal-based products on the levels of deoxynivalenol, total aflatoxin, ochratoxin A, and zearalenone: A systematic review and meta-analysis. Food Chem. 2018, 268, 611-624. [CrossRef]

5. Cortinovis, C.; Pizzo, F.; Spicer, L.J.; Caloni, F. Fusarium mycotoxins: Effects on reproductive function in domestic animals-A review. Theriogenology 2013, 80, 557-564. [CrossRef] [PubMed]

6. Halenar, M.; Medvedova, M.; Maruniakova, N.; Kolesarova, A. Assessment of a potential preventive ability of amygdalin in mycotoxin-induced ovarian toxicity. J. Environ. Sci. Health B 2015, 50, 411-416. [CrossRef]

7. Kolesarova, A.; Medvedova, M.; Halenar, M.; Sirotkin, A.V.; Bulla, J. The influence of deoxynivalenol and zearalenone on steroid hormone production by porcine ovarian granulosa cells in vitro. J. Environ. Sci. Health B 2017, 52, 823-832. [CrossRef]

8. Zhang, G.L.; Feng, Y.L.; Song, J.L.; Zhou, X.S. Zearalenone: A Mycotoxin with Different Toxic Effect in Domestic and Laboratory Animals' Granulosa Cells. Front. Genet. 2018, 9, 667. [CrossRef]

9. Rotter, B.A.; Prelusky, D.B.; Pestka, J.J. Toxicology of deoxynivalenol (vomitoxin). J. Toxicol. Environ. Health 1996, 48, 1-34. [CrossRef]

10. Poor, M.; Kunsagi-Mate, S.; Sali, N.; Koszegi, T.; Szente, L.; Peles-Lemli, B. Interactions of zearalenone with native and chemically modified cyclodextrins and their potential utilization. J. Photochem. Photobiol. B 2015, 151, 63-68. [CrossRef]

11. Vanyi, A.; Bata, A.; Glavits, R.; Kovacs, F. Perinatal oestrogen syndrome in swine. Acta Vet. Hung. 1994, 42, 433-446. [PubMed]

12. Dacasto, M.; Rolando, P.; Nachtmann, C.; Ceppa, L.; Nebbia, C. Zearalenone mycotoxicosis in piglets suckling sows fed contaminated grain. Vet. Hum. Toxicol. 1995, 37, 359-361.

13. Osweiler, G.D.; Stahr, H.M.; Beran, G.W. Relationship of mycotoxins to swine reproductive failure. J. Vet. Diagn. Investig. 1990, 2, 73-75. [CrossRef]

14. Zwierzchowski, W.; Przybylowicz, M.; Obremski, K.; Zielonka, L.; Skorska-Wyszynska, E.; Gajecka, M.; Polak, M.; Jakimiuk, E.; Jana, B.; Rybarczyk, L.; et al. Level of zearalenone in blood serum and lesions in ovarian follicles of sexually immature gilts in the course of zearalenone micotoxicosis. Pol. J. Vet. Sci. 2005, 8, 209-218.

15. Lai, F.N.; Ma, J.Y.; Liu, J.C.; Wang, J.J.; Cheng, S.F.; Sun, X.F.; Li, L.; Li, B.; Nyachoti, C.M.; Shen, W. The influence of Nacetyl-1-cysteine on damage of porcine oocyte exposed to zearalenone in vitro. Toxicol. Appl. Pharmacol. 2015, 289, 341-348. [CrossRef]

16. Canisso, I.F.; Carvalho, G.R.; Morel, M.C.; Guimaraes, J.D.; McDonnell, S.M. Sexual behavior and ejaculate characteristics in Pega donkeys (Equus asinus) mounting estrous horse mares (Equus caballus). Theriogenology 2010, 73, 56-63. [CrossRef]

17. Canisso, I.F.; Carvalho, G.R.; Morel, M.D.; Ker, P.G.; Rodrigues, A.L.; Silva, E.C.; Coutinho Da Silva, M.A. Seminal parameters and field fertility of cryopreserved donkey jack semen after insemination of horse mares. Equine Vet. J. 2011, 43, 179-183. [CrossRef]

18. Cong, W.; Chen, L.; Shan, X.F.; Qian, A.D.; Meng, Q.F. First genetic characterization of Toxoplasma gondii infection in donkey meat slaughtered for human consumption in Shandong province, eastern China. Infect. Genet. Evol. 2018, 61, 1-3. [CrossRef]

19. Zhu, M.; Weng, Q. China: Will the donkey become the next pangolin? Equine Vet. J. 2018, 50, 276. [CrossRef]

20. Zhang, G.L.; Zhang, R.Q.; Sun, X.F.; Cheng, S.F.; Wang, Y.F.; Ji, C.L.; Feng, Y.Z.; Yu, J.; Ge, W.; Zhao, Y.; et al. RNA-seq based gene expression analysis of ovarian granulosa cells exposed to zearalenone in vitro: Significance to steroidogenesis. Oncotarget 2017, 8 , 64001-64014. [CrossRef]

21. Minervini, F.; Giannoccaro, A.; Fornelli, F.; Dell'Aquila, M.E.; Minoia, P.; Visconti, A. Influence of mycotoxin zearalenone and its derivatives (alpha and beta zearalenol) on apoptosis and proliferation of cultured granulosa cells from equine ovaries. Reprod. Biol. Endocrinol. 2006, 4, 62. [CrossRef]

22. Christine Arnesen, M.; Marie-Lisa Eich, M.; Maria, D.C.; Rodriguez Pena, M.; Jaclyn, R.; Cappel, M.; Lauren Schwartz, M.; Soroush Rais-Bahrami, M.; Sheila, F.; Faraj, M.; et al. NKX3.1 and prostein expression in testicular tissue and sex cord-stromal tumors. Am. J. Surg. Pathol. 2020, 44, 61-67. [CrossRef]

23. Khaleel, I.; Al-Obaidy, M.; Muhammad, T.; Idrees, M.; David, J.; Grignon, M.; Thomas, M.; Ulbright, M. Adenocarcinoma of the rete testis clinicopathologic and immunohistochemical characterization of 6 cases and review of the literature. Am. J. Surg. Pathol. 2019, 43, 670-681.

24. Gelmann, E.P.; Bowen, C.; Bubendorf, L. Expression of NKX3.1 in normal and malignant tissues. Prostate 2003, 55, 111-117. [CrossRef]

25. Food and Drug Administration. Food and Drug Administration (FDA) Mycotoxin Regulatory Guidance; National Grain and Feed Association: Washington, DC, USA, 2011; pp. 1-9.

26. EFSA Contam Panel. Scientific opinion on risk for animal health related to the presence of zearalenone and its modified forms in feed. EFSA J. 2017, 15, 4851. 
27. Chang, Y.F.; Lee-Chang, J.S.; Panneerdoss, S.; MacLean, J.A., 2nd; Rao, M.K. Isolation of Sertoli, Leydig, and spermatogenic cells from the mouse testis. Biotechniques 2011, 51, 341-342. [CrossRef]

28. Dance, A.; Kastelic, J.; Thundathil, J. A combination of insulin-like growth factor I (IGF-I) and FSH promotes proliferation of prepubertal bovine Sertoli cells isolated and cultured in vitro. Reprod. Fertil. Dev. 2017, 29, 1635-1641. [CrossRef] [PubMed]

29. Jegou, B. The Sertoli cell in vivo and in vitro. Cell Biol. Toxicol. 1992, 8, 49-54. [CrossRef]

30. Sharpe, R.M.; McKinnell, C.; Kivlin, C.; Fisher, J.S. Proliferation and functional maturation of Sertoli cells, and their relevance to disorders of testis function in adulthood. Reproduction 2003, 125, 769-784. [CrossRef]

31. Tarulli, G.A.; Stanton, P.G.; Meachem, S.J. Is the Adult Sertoli Cell Terminally Differentiated? Biol. Reprod. 2012, 87, 1-11. [CrossRef]

32. Orth, J.M.; Gunsalus, G.L.; Lamperti, A.A. Evidence from Sertoli cell-depleted rats indicates that spermatid number in adults depends on numbers of Sertoli cells produced during perinatal development. Endocrinology 1988, 122, 787-794. [CrossRef]

33. Chang, L.; Wang, J.; She, R.; Ma, L.; Wu, Q. In vitro toxicity evaluation of melamine on mouse TM4 Sertoli cells. Environ. Toxicol. Pharmacol. 2017, 50, 111-118. [CrossRef]

34. Mariana, R.; Marcelo, R.G.; Noel, G.M.; Herminia, P.E.; Beatriz, C.S.; Beatriz, M.S.; Fernanda, R.M. Germ cells regulate 3hydroxybutyrate production in rat Sertoli cells. Gen. Comp. Endocrinol. 2017, 248, 5-15.

35. Zhang, G.L.; Song, J.L.; Ji, C.L.; Feng, Y.L.; Yu, J.; Nyachoti, C.M.; Yang, G.S. Zearalenone Exposure Enhanced the Expression of Tumorigenesis Genes in Donkey Granulosa Cells via the PTEN/PI3K/AKT Signaling Pathway. Front. Genet. 2018, 9, 293. [CrossRef]

36. Zhang, P.; Chao, H.; Sun, X.; Li, L.; Shi, Q.; Shen, W. Murine folliculogenesis in vitro is stage-specifically regulated by insulin via the Akt signaling pathway. Histochem. Cell Biol. 2010, 134, 75-82. [CrossRef] [PubMed]

37. Chao, H.H.; Zhang, X.F.; Chen, B.; Pan, B.; Zhang, L.J.; Li, L.; Sun, X.F.; Shi, Q.H.; Shen, W. Bisphenol A exposure modifies methylation of imprinted genes in mouse oocytes via the estrogen receptor signaling pathway. Histochem. Cell Biol. 2012, 137, 249-259. [CrossRef]

38. Pan, B.; Chao, H.; Chen, B.; Zhang, L.; Li, L.; Sun, X.; Shen, W. DNA methylation of germ-cell-specific basic helix-loop-helix (HLH) transcription factors, Sohlh2 and Figlalpha during gametogenesis. Mol. Hum. Reprod. 2011, 17, 550-561. [CrossRef] [PubMed]

39. Zhang, G.L.; Song, J.L.; Zhou, Y.; Zhang, R.Q.; Cheng, S.F.; Sun, X.F.; Qin, G.Q.; Shen, W.; Li, L. Differentiation of sow and mouse ovarian granulosa cells exposed to zearalenone in vitro using RNA-seq gene expression. Toxicol. Appl. Pharmacol. 2018, 350, 78-90. [CrossRef] [PubMed]

40. Benjamini, Y.; Drai, D.; Elmer, G.; Kafkafi, N.; Golani, I. Controlling the false discovery rate in behavior genetics research. Behav. Brain Res. 2001, 125, 279-284. [CrossRef]

41. Luo, W.; Brouwer, C. Pathview: An R/Bioconductor package for pathway-based data integration and visualization. Bioinformatics 2013, 29, 1830-1831. [CrossRef]

42. Hemendinger, R.A.; Gores, P.; Blacksten, L.; Harley, V.; Halberstadt, C. Identification of a specific Sertoli cell marker, Sox9, for use in transplantation. Cell Transplant. 2002, 11, 499-505. [CrossRef] [PubMed]

43. Franceschini, A.; Szklarczyk, D.; Frankild, S.; Kuhn, M.; Simonovic, M.; Roth, A.; Lin, J.; Minguez, P.; Bork, P.; Mering, C.v.; et al. STRING v9.1: Protein-protein interaction networks, with increased coverage and integration. Nucleic Acids Res. 2013, $41,808-815$. [CrossRef] [PubMed]

44. Chen, X.; He, W.T.; Hu, L.C.; Li, J.X.; Fang, Y.; Wang, X.; Xu, X.Z.; Wang, Z.; Huang, K.; Han, J.H. Pyroptosis is driven by non-selective gasdermin-D pore and its morphology is different from MLKL channel-mediated necroptosis. Cell Res. 2016, 26, 1007-1020. [CrossRef]

45. Kouadio, J.H.; Mobio, T.A.; Baudrimont, I.; Moukha, S.; Dano, S.D.; Creppy, E.E. Comparative study of cytotoxicity and oxidative stress induced by deoxynivalenol, zearalenone or fumonisin B1 in human intestinal cell line Caco-2. Toxicology 2005, 213, 56-65. [CrossRef]

46. Larsen, J.C.; Hunt, J.; Perrin, I.; Ruckenbauer, P. Workshop on trichothecenes with a focus on DON: Summary report. Toxicol. Lett. 2004, 153, 1-22. [CrossRef]

47. Sprando, R.L.; Pestka, J.; Collins, T.F.; Rorie, J.; O’Donnell, M.; Hinton, D.; Chirtel, S. The effect of vomitoxin (Deoxnivalenol) on testicular morphology, testicular spermatid counts and epididymal sperm counts in IL-6KO [B6129-IL6 [TmlKopf] (IL-6 gene deficient)] and WT [B6129F2 (wild type to B6129-IL6 with an intact IL-6 gene)] mice. Food Chem. Toxicol. 1999, 37, 1073-1079. [CrossRef]

48. Kiang, D.T.; Kennedy, B.J.; Pathre, S.V.; Mirocha, C.J. Binding characteristics of zearalenone analogs to estrogen receptors. Cancer Res. 1978, 38 Pt 1, 3611-3615.

49. Nikov, G.N.; Hopkins, N.E.; Boue, S.; Alworth, W.L. Interactions of dietary estrogens with human estrogen receptors and the effect on estrogen receptor-estrogen response element complex formation. Environ. Health Perspect. 2000, 108, 867-872. [CrossRef]

50. Mehmood, Z.; Smith, A.G.; Tucker, M.J.; Chuzel, F.; Carmichael, N.G. The development of methods for assessing the in vivo oestrogen-like effects of xenobiotics in CD-1 mice. Food Chem. Toxicol. 2000, 38, 493-501. [CrossRef]

51. Mueller, S.O.; Simon, S.; Chae, K.; Metzler, M.; Korach, K.S. Phytoestrogens and their human metabolites show distinct agonistic and antagonistic properties on estrogen receptor alpha (ERalpha) and ERbeta in human cells. Toxicol. Sci. 2004, 80, 14-25. [CrossRef] [PubMed] 
52. Albonico, M.; Schutz, L.F.; Caloni, F.; Cortinovis, C.; Spicer, L.J. Toxicological effects of fumonisin B1 alone and in combination with other fusariotoxins on bovine granulosa cells. Toxicon 2016, 118, 47-53. [CrossRef]

53. Abbes, S.; Ouanes, Z.; ben Salah-Abbes, J.; Houas, Z.; Oueslati, R.; Bacha, H.; Othman, O. The protective effect of hydrated sodium calcium aluminosilicate against haematological, biochemical and pathological changes induced by Zearalenone in mice. Toxicon 2006, 47, 567-574. [CrossRef]

54. Abbes, S.; Salah-Abbes, J.B.; Ouanes, Z.; Houas, Z.; Othman, O.; Bacha, H.; Abdel-Wahhab, M.A.; Oueslati, R. Preventive role of phyllosilicate clay on the Immunological and Biochemical toxicity of zearalenone in Balb/c mice. Int. Immunopharmacol. 2006, 6, 1251-1258. [CrossRef] [PubMed]

55. Luongo, D.; Severino, L.; Bergamo, P.; De Luna, R.; Lucisano, A.; Rossi, M. Interactive effects of fumonisin B1 and alpha-zearalenol on proliferation and cytokine expression in Jurkat T cells. Toxicol. In Vitro 2006, 20, 1403-1410. [CrossRef] [PubMed]

56. Ling, A.; Sun, L.; Guo, W.; Sun, S.; Yang, J.; Zhao, Z. Individual and combined cytotoxic effects of T-2 toxin and its four metabolites on porcine Leydig cells. Food Chem. Toxicol. 2020, 139, 111277. [CrossRef] [PubMed]

57. Zhu, L.; Jia, B.P.; Cao, L.; Xu, J.R.; Zhao, J.; Feng, S.B.; Li, Y.; Wu, J.J.; Wang, X.C. Effect of sertoli cells apoptosis in piglets induced by single or combined administration of zearalenone and deoxynivalenol. Acta Agric. Zhejiangensis 2020, 32, 1954-1962. (In Chinese)

58. Cao, L.; Zhao, J.; Xu, J.; Zhu, L.; Rahman, S.U.; Feng, S.; Li, Y.; Wu, J.; Wang, X. N-acetylcysteine ameliorate cytotoxic injury in piglets sertoli cells induced by zearalenone and deoxynivalenol. Environ. Sci. Pollut. Res. Int. 2021. online ahead of print. [CrossRef]

59. Wan, L.Y.; Woo, C.S.; Turner, P.C.; Wan, J.M.; El-Nezami, H. Individual and combined effects of Fusarium toxins on the mRNA expression of pro-inflammatory cytokines in swine jejunal epithelial cells. Toxicol. Lett. 2013, 220, 238-246. [CrossRef]

60. Wan, L.Y.; Turner, P.C.; El-Nezami, H. Individual and combined cytotoxic effects of Fusarium toxins (deoxynivalenol, nivalenol, zearalenone and fumonisins B1) on swine jejunal epithelial cells. Food Chem. Toxicol. 2013, 57, 276-283. [CrossRef]

61. Kesavardhana, S.; Malireddi, R.K.S.; Kanneganti, T.D. Caspases in Cell Death, Inflammation, and Pyroptosis. Ann. Rev. Immunol. 2020, 38, 567-595. [CrossRef]

62. Van Opdenbosch, N.; Lamkanfi, M. Caspases in Cell Death, Inflammation, and Disease. Immunity 2019, 50, 1352-1364. [CrossRef]

63. Shi, J.; Zhao, Y.; Wang, K.; Shi, X.; Wang, Y.; Huang, H.; Zhuang, Y.; Cai, T.; Wang, F.; Shao, F. Cleavage of GSDMD by inflammatory caspases determines pyroptotic cell death. Nature 2015, 526, 660-665. [CrossRef]

64. Kayagaki, N.; Stowe, I.B.; Lee, B.L.; O’Rourke, K.; Anderson, K.; Warming, S.; Cuellar, T.; Haley, B.; Roose-Girma, M.; Phung, Q.T.; et al. Caspase-11 cleaves gasdermin D for non-canonical inflammasome signalling. Nature 2015, 526, 666-671. [CrossRef] [PubMed]

65. Fang, Y.; Tian, S.; Pan, Y.; Li, W.; Wang, Q.; Tang, Y.; Yu, T.; Wu, X.; Shi, Y.; Ma, P.; et al. Pyroptosis: A new frontier in cancer. Biomed. Pharmacother. 2020, 121, 109595. [CrossRef] [PubMed]

66. Trump, B.F.; Goldblatt, P.J.; Stowell, R.E. Studies of necrosis in vitro of mouse hepatic parenchymal cells. Ultrastructural alterations in endoplasmic reticulum, Golgi apparatus, plasma membrane, and lipid droplets. Lab. Investig. 1965, 14, 2000-2028. [PubMed]

67. Xue, Y.; Enosi Tuipulotu, D.; Tan, W.H.; Kay, C.; Man, S.M. Emerging Activators and Regulators of Inflammasomes and Pyroptosis. Trends Immunol. 2019, 40, 1035-1052. [CrossRef]

68. Szarek, M.; Bergmann, M.; Konrad, L.; Schuppe, H.C.; Kliesch, S.; Hedger, M.P.; Loveland, K.L. Activin A target genes are differentially expressed between normal and neoplastic adult human testes: Clues to gonocyte fate choice. Andrology 2019, 7, 31-41. [CrossRef]

69. Kim, B.; Lee, H.J.; Im, N.R.; Lee, D.Y.; Kim, H.K.; Kang, C.Y.; Park, I.H.; Lee, S.H.; Lee, H.M.; Lee, S.H.; et al. Decreased expression of CCL17 in the disrupted nasal polyp epithelium and its regulation by IL-4 and IL-5. PLoS ONE 2018, 13, e0197355. [CrossRef]

70. Naumann, S.C.; Roos, W.P.; Jost, E.; Belohlavek, C.; Lennerz, V.; Schmidt, C.W.; Christmann, M.; Kaina, B. Temozolomide- and fotemustine-induced apoptosis in human malignant melanoma cells: Response related to MGMT, MMR, DSBs, and p53. Br. J. Cancer 2009, 100, 322-333. [CrossRef]

71. Felsberg, J.; Thon, N.; Eigenbrod, S.; Hentschel, B.; Sabel, M.C.; Westphal, M.; Schackert, G.; Kreth, F.W.; Pietsch, T.; Loffler, M.; et al. Promoter methylation and expression of MGMT and the DNA mismatch repair genes MLH1, MSH2, MSH6 and PMS2 in paired primary and recurrent glioblastomas. Int. J. Cancer 2011, 129, 659-670. [CrossRef] [PubMed]

72. Yuan, J.; Kramer, A.; Matthess, Y.; Yan, R.; Spankuch, B.; Gatje, R.; Knecht, R.; Kaufmann, M.; Strebhardt, K. Stable gene silencing of cyclin B1 in tumor cells increases susceptibility to taxol and leads to growth arrest in vivo. Oncogene 2006, 25, 1753-1762. [CrossRef] [PubMed]

73. Wang, A.; Yoshimi, N.; Ino, N.; Tanaka, T.; Mori, H. Overexpression of cyclin B1 in human colorectal cancers. J. Cancer Res. Clin. Oncol. 1997, 123, 124-127. [CrossRef]

74. Mashal, R.D.; Lester, S.; Corless, C.; Richie, J.P.; Chandra, R.; Propert, K.J.; Dutta, A. Expression of cell cycle-regulated proteins in prostate cancer. Cancer Res. 1996, 56, 4159-4163. [PubMed]

75. Kushner, J.; Bradley, G.; Young, B.; Jordan, R.C. Aberrant expression of cyclin A and cyclin B1 proteins in oral carcinoma. J. Oral Pathol Med. 1999, 28, 77-81. [CrossRef] [PubMed] 
76. Kawamoto, H.; Koizumi, H.; Uchikoshi, T. Expression of the G2-M checkpoint regulators cyclin B1 and cdc2 in nonmalignant and malignant human breast lesions: Immunocytochemical and quantitative image analyses. Am. J. Pathol. 1997, 150, 15-23. [PubMed]

77. Suzuki, T.; Urano, T.; Miki, Y.; Moriya, T.; Akahira, J.; Ishida, T.; Horie, K.; Inoue, S.; Sasano, H. Nuclear cyclin B1 in human breast carcinoma as a potent prognostic factor. Cancer Sci. 2007, 98, 644-651. [CrossRef] 